\title{
Jolanta Sztachelska*
}

\section{Witkiewicz czyta Sienkiewicza*}

DOI: http://dx.doi.org/10.12775/LC.2018.003

Streszczenie: W artykule zostały omówione relacje między Witkiewiczem a Sienkiewiczem wynikające z przynależności obu autorów do jednej generacji i formacji myślowej, a także z łączącego pisarzy zainteresowania kwestiami estetycznymi i zaangażowania w sprawy polskie. W celu prześledzenia okoliczności „lekturowego dialogu” zostały przywołane Sienkiewiczowskie i Witkiewiczowskie felietony, recenzje, korespondencje, utwory literackie oraz artykuły i monografie artystyczne.

Słowa kluczowe: Stanisław Witkiewicz, Henryk Sienkiewicz, sztuka, idea polska

\section{Witkiewicz reads Sienkiewicz}

\begin{abstract}
In this paper the relationships between Witkiewicz and Sienkiewicz have been discussed. Those connections resulted from the affiliation to the same generation and community of thought as well as from the interest in ethical issues and engagement in Polish question. In order to examine the circumstances of "reading's dialogue", various works of Sienkiewicz and Witkiewicz have been mentioned and analyzed: feuilletons, reviews, correspondence, literary works, articles and artistic monographs.
\end{abstract}

Keywords: Stanisław Witkiewicz, Henryk Sienkiewicz, art, Polish idea

\footnotetext{
* Dr hab., prof. UwB, kierownik Zakładu Pozytywizmu i Młodej Polski na Uniwersytecie w Białymstoku. Historyk literatury, znawca literatury polskiej i kultury XIX i XX wieku. E-mail: jsztachelska@wp.eu.

** Artykuł powstał w ramach pracy nad grantem NCN -2012/06/A/HS2/00252.
} 
ostatnim pożegnaniu, w przemówieniu, które dedykuje się zmarłemu, zwykle występuje jeden bohater. Stefan Żeromski w oracji napisanej po śmierci Sienkiewicza efektownie tę regułę łamie. Autora Trylogii wymienia na końcu, wcześniej natomiast przypomina zasługi dwóch innych osobistości, które - podobnie jak Sienkiewicz - głęboko, całym życiem przysłużyły się Polsce. Na pierwszym miejscu stawia Tomasza Teodora Jeża - niezłomnego demokratę, szukającego wolności dla swej ojczyzny na wszystkich szlakach Europy. Na drugim - wymienia Stanisława Witkiewicza, zgasłego w 1915 roku. Obaj nie doczekali niepodległości, nie zostali też docenieni za swe zasługi. Żeromski nie waha się więc przed zbudowaniem retorycznej triady:

Jeżeli tamci dwaj pracownicy osiągnęli trudami swymi, każdy we własnej dziedzinie, sumę nowych wartości w narodzie i podwyższyli stopień jego zjednoczenia się w społeczeństwo dostojne pośród rodziny ludów, to Henryk Sienkiewicz osiągnął najwyższy gradus tej skali. Jest to rzeczywiście zjawisko niezwykłe, ażeby człowiek nie obdarzony zakresem władzy, przekazanej mu przez inną władzę, ani siły, wręczonej mu przez siłę zbiorową, lecz własną jedynie wewnętrzną mocą, przekazaną nietrwałemu pismu, mógł osiągnąć potęgę tak iście hetmańską (Żeromski 1928: 167).

Każdy aspekt tego przemówienia - jego retoryka, wysoki styl, emocjonalność - podkreślają podziw i szacunek, jakim Żeromski darzy zmarłego. Tym bardziej zastanawiający wydaje się zatem zbudowany przy tej okazji portret Stanisława Witkiewicza. Wśród krwawych dni wojennych - pisze autor Popiołów - zamknęły się także

jasne oczy Stanisława Witkiewicza, aż do starości oczy dziecka prawdomównego, które z najgłębszym na pokolenie entuzjazmem i z najbezwzględniejszą szczerością szukały w tym świecie tego, co jest jedyną pociechą wśród tylu nędz i jedynym dobrem wśród tak wielkiego zalewu ohydy - objawów piękna wiecznego (ibid.: 166).

Te oczy - pisze dalej z rozmachem autor - obserwowały inną scenę niż ta, w której aktorem był Tomasz Teodor Jeż. Dziecięce oczy Witkiewicza „widziały Sybir, katownię ojca i matki”, młodzieńcze - Petersburg doby popowstaniowej - „z jego środowiskiem polskim rozbitym jak owce przez wilki” i „Warszawę z poddaszami wielkich później artystów”. Później także Monachium pełne rozbitków po 1863 roku. Męskie zobaczyły „Zakopane z jego dawnym światem”, „w dobie braterstwa z ludem” i docenienia jego oryginalnej sztuki, natomiast sędziwe wpatrywały się w cichą zatokę Quarnero, w której wodach odbijał się „obraz wieczności” (ibid.) $)^{1}$.

Cytat może przydługi, ale ważny ze względu na walory obrazowe. Zwłaszcza metafora „prawdomównego dziecka” patrzącego na świat szeroko rozwartymi oczami wydaje się trafna jako próba uchwycenia osobowości Witkiewicza i głęboko przemawia do wyobraźni. Tak oto w syntetycznym skrócie udaje się Żeromskiemu uchwycić wyjątkowość losu i doświadczenia jednej z najważniejszych postaci polskiego życia artystycznego i umysłowego drugiej połowy XIX wieku.

\footnotetext{
1 Cytat zmodyfikowałam dla potrzeb artykułu.
} 
Wróćmy jednak do zestawienia Witkiewicz-Sienkiewicz. Nie jest ono przypadkiem ani li tylko wykorzystaniem okoliczności sąsiedztwa zgonów (1915-1916). Obaj należą do tej samej generacji i jednej formacji myślowej. Obaj są też fascynującymi pisarzami: jeden zasilił wyobraźnię narodową, dając swoim rodakom epicką powieść z lat dawnych, drugi chciał kształtować ducha, ucząc rozumienia piękna i walcząc o odrodzenie idei polskiej.

Tworzyli razem niepowtarzalną konfigurację, bo los to łączył ich, to rozdzielał, stawiając nieraz po przeciwnych stronach, choć rozumieli się jak nikt przed nimi. W książce, w której po raz pierwszy opisywałam ich relację, nazwałam to spotkaniami na kładkach (rozdział Sienkiewicz-Witkiewicz, czyli kładki, na których spotykaja się ludzie z różnych światów; Sztachelska 2003: 168-203). Mosty, rzucone przez rzekę, dają możliwość spotkania się ludzi z różnych światów. Trudno, by nie łączyły tych, dla których zawsze najważniejsze były sztuka i Polska.

\section{Kładki i ... kładka}

W książce pt. Czar i zaklęcie Sienkiewicza (ibid.), pisząc o dwojgu ludziach z przeciwstawnych sobie brzegów, brałam pod uwagę przede wszystkim zakończenie ich historii życiowych, role, w których ukazali się światu. Po jednej stronie Sienkiewicz - światowa sława, najbardziej znany na świecie reprezentant polskiej kultury, po drugiej - charyzmatyczna postać Witkiewicza, funkcjonująca na antypodach tego, co uznajemy za sukces - wielkość, ale zastygła w lokalności, wycofana, zepchnięta na margines. Dzisiaj także wyraźnie przytłumiona przez międzynarodowy sukces syna, Stanisława Ignacego, z którym mylą go nie tylko popularne portale internetowe, ale także niezbyt bystrzy współcześni konsumenci kultury. Witkiewicz, inaczej niż Witkacy², nigdy nie trafił do programów szkolnych, a choć nieraz szokował i bulwersował bliźnich, nie miał i nie ma statusu dyżurnego błazna i awangardzisty polskiej kultury. Pozostał autorytetem lokalnym, nigdy nie przebił się do mainstreamu cenią go i szanują przede wszystkim specjaliści, głównie historycy sztuki i literaturoznawcy. Kładki, na których rozpatrywałam relacje między Sienkiewiczem i Witkiewiczem, umownie określały te wszystkie sytuacje, które mogły ich wiązać i zderzać ze sobą - przynależność pokoleniowa, kwestie estetyczne, zaangażowanie w sprawy polskie, miłość do Tatr. Wrócę do niektórych.

Pierwsza kładka to podobna sytuacja startu życiowego. Podobna tylko do pewnego stopnia, bo i jednocześnie diametralnie odmienna. Sienkiewicz w Warszawie to prowincjusz z aspiracjami, zawsze, według relacji rówieśników, np. Świętochowskiego, trzymający się na uboczu, ale - jednak - znakomicie radzący sobie nawet w niezbyt życzliwym środowisku. W dziennikarstwie, jeszcze przed wyjazdem do Ameryki (1876) - osobny, a to dzięki odwadze w podejmowaniu drażliwych tematów i świetnemu stylowi. Jednym słowem, ktoś, o kim z zazdrością mówiło się: „publicystyczny pazur”. Po powrocie (1879) wyraźnie odmieniony, opromieniony sukcesem Listów z Ameryki, które namiętnie czytała Warszawa

2 Relacje między tymi dwiema silnymi osobowościami stanowią jakby oddzielny nurt w rozważaniach na temat ich wkładu w polską kulturę. Na ten temat m.in.: Sztaba 1982; Piasecki 1999: 196-255; Błoński 2003; Vražić 2013. Na temat poglądów Witkiewicza: Pycka 2010. 
i nie tylko, mimo zrazu niepewnej sytuacji, szedł po linii wznoszącej - jego kariera nabierała tempa. Witkiewicz z kolei w Polsce pojawia się incognito, jest jednym z wielu, którego srodze naznaczył los. Jest w kraju po raz pierwszy w 1868, próbując wyjednać coś w sprawie skrócenia zesłania braci, potem pojawia się w Warszawie na jesieni 1871, a następnie po kilku latach pobytu w Monachium w 1875 roku. I za pierwszym, za drugim i trzecim razem jak utrzymuje na postawie dokumentów rodzinnych Kazimierz Kosiński - Witkiewicz doznawał tu szoku3 ${ }^{3}$. Wychowany na zsyłce przez rozkochanych w Polsce rodziców miał swoje przekonania i oczekiwania - od początku chciał więcej, oczekiwał spełnienia marzeń. To, co miał okazję zobaczyć w Polsce postyczniowej, napełniało go zgrozą i przerażeniem. Nie umiał odnaleźć się w atmosferze powszechnie akceptowanej zgody na niewolę, obcy mu był kompromis i konformizm większości. Młodszy od Sienkiewicza o pięć lat, przerastał go doświadczeniem życiowym, dojrzałością, radykalizmem. Wszystko w nim było inne, oryginalne, autentyczne: zachowanie, język, ubiór. Gdy Sienkiewicz, mimo biedy, która była chlebem codziennym większości pozytywistów, uchodził za człowieka z wrodzoną dystynkcją, nieomalże dandysa, Witkiewicz szokował nawet wyglądem. We wspomnieniach z epoki czytamy, że zwykł był ubierać się jak prosty robotnik, w niebieską bluzę ${ }^{4}$. Gdy w takim ubraniu zbliżał się do dorożki wiozącej powszechnie rozpoznawalną gwiazdę sceny warszawskiej, Helenę Modrzejewską, ludzie na ulicy wstrzymywali dech. Na wielu zdjęciach i portretach z epoki widnieje ubrany w sybiracką burkę. Zrosła się z jego wizerunkiem, stanowiąc część jego egzotycznego, niekonwencjonalnego wyglądu.

W latach siedemdziesiątych Stanisław Witkiewicz przemieszkiwał z innymi malarzami (Józefem Chełmońskim i Adamem Chmielowskim) w pomieszczeniu dla praczek na poddaszu Hotelu Europejskiego. Stworzyli tam wspólnie coś w rodzaju artystycznej pracowni - enklawę wolności, przestrzeń, w której rodziły się idee i dojrzewały talenty. Z rzadka tylko bywając w lepszym towarzystwie, spotykali się w demokratycznym salonie hrabiny Chłapowskiej (Heleny Modrzejewskiej) - i Sienkiewicz, i Witkiewicz, obaj w nią wpatrzeni, może nawet (tego chce legenda) rywalizujący o jej względy? Nic dziwnego więc, że gdy znużona stosunkami warszawskimi gwiazda rzuciła od niechcenia, że myśli o wyjeździe za granicę, a Sienkiewicz (tak jest we wspomnieniach i listach aktorki) napomknął o Ameryce, obaj zadeklarowali chęć wyjazdu. Sienkiewicz potrafil zainteresować podróżą sponsora - „Gazeta Polska”, która wyłożyła na ten cel pieniądze, dzięki jego błyskotliwym korespondencjom i napisanym w Ameryce utworom, przez lata utrzymała się na trudnym rynku warszawskim i cieszyła się powodzeniem. Witkiewicz niczego nie przedsięwziął, tłumaczył się chorobą, zmianą planów, ale we wspomnieniach o bracie Maria Witkiewiczówna wyjawia, że prawdziwym powodem był, jak zwykle, brak pieniędzy. Jak dotkliwy, można się tylko domyślać, a dowiedzieć jedynie cząstkowo, m.in. z jego listów, w których malaria z Europejskiego żyje powietrzem, miłością i sztuką.

W latach siedemdziesiątych nasi bohaterowie intensywnie ze sobą korespondują, niestety korespondencja ta nie zachowała się do naszych czasów. Zwłaszcza listy Sienkiewicza z pobytu w Ameryce mogłyby być ciekawe. Witkiewiczowi wszyscy jego korespondenci

\footnotetext{
3 „Po przyjeździe do kraju doznał Witkiewicz wstrząsających uczuć na widok martwoty, wytrzeźwienia się z idealizmu, braku uczuć potężnych z tęsknotą do niepodległości” (Kosiński 1928: 14).

4 Pisze Kosiński: „Chodził, jak robotnik, w bluzie robotniczej, w przeświadczeniu, że jest nim w istocie” (ibid.: 38). Autor odwołuje się do wspomnień siostry malarza, Marii Witkiewiczówny. Zob. także Modrzejewska 1957: 246.
} 
mówili zawsze więcej niż innym ${ }^{5}$ - wzbudzał zaufanie bezwzględne, można mu było powierzyć absolutnie wszystko. Pewnie dlatego na początku lat osiemdziesiątych Witkiewicz odegrał w biografii przyjaciela rolę poufnego „postillon d’amour” - pośredniczył w kontaktach między zakochanym Litwosem i swoją krajanką, Marią Szetkiewiczówną, poznaną w czasie kuracji w Meranie. W listach późniejszych, pisanych już po powrocie z Ameryki, Sienkiewicz wyznawał mu to, czego skąpił innym - otwarcie mówił o ekstatycznym doświadczeniu wolności, której tam zaznał, o znużeniu Polską, o marzeniu powrotu do Stanów, bo - na zawsze jest i będzie - „człowiekiem z Kanionu” (Sienkiewicz 2009: 318). Ciekawe, czy gdyby wyjazd ten doszedł do skutku, mielibyśmy Sienkiewicza, jakiego znamy? A Witkiewicz? Czy, gdyby jednak pojechał do Ameryki, wróciłby odmieniony jak Litwos? A może jednak byłby to odwrót podobny do Norwidowego?

Witkiewicz znika z Warszawy, gdy Sienkiewicz udaje się do Ameryki. Ponownie spotykają się już w innej sytuacji życiowej - Litwos opromieniony sławą amerykańskiej korespondencji, Witkiewicz natomiast po pobycie w Monachium, w czasie którego ogromnie rozwinął się jako artysta. Jeden wraca z zagranicy, by z Litwosa stać się Henrykiem Sienkiewiczem - wielkim polskim pisarzem, drugi, by zrealizować się jako krytyk sztuki i artysta. Jeszcze na początku lat osiemdziesiątych czują się mocno ze sobą związani, znają swoje dokonania, wzajemnie obserwują rozwój swoich karier.

\section{Znikczemnienie i sztuka u nas}

W liście nadesłanym 19 maja 1878 roku z odbywającej się wtedy w Paryżu Wielkiej Wystawy Światowej korespondent „Gazety Polskiej” informował, jak prezentują się na niej sztuki piękne. Oglądając kolejne pawilony narodowe, zżymał się na brak jakiegokolwiek, choćby tematycznego klucza rozmieszczonych dzieł, przeszkadzała mu nieobecność podpisów pod obrazami i katalogów. Jedno tylko nie umknęło jego uwadze. Wśród dzieł najnowszych i wzbudzających powszechne zainteresowanie Polacy zajmują jedno z pierwszych miejsc.

Korespondentem był oczywiście Sienkiewicz, który po powrocie z Ameryki przez niemal rok zatrzymał się we Francji. Na paryskiej wystawie wyłuskiwał z satysfakcją nazwiska rodaków. Tak, są tu nasi najwięksi - pisał: Matejko, Siemiradzki, Brandt, Maksymilian Gierymski. Ciesząc się ich powodzeniem, ubolewał jednak, iż tylko on wie, że są Polakami. Cudzoziemcom - konstatował z goryczą - nie zaświta to przecież w głowie, tak jak nie przyjdzie im na myśl, że w ogóle istnieje jakaś sztuka polska:

Obrazy wspomnianych mistrzów nie stoją obok siebie - i nie przedstawiają całości samej w sobie. Matejko figuruje w oddziale austriackim, Siemiradzki w rosyjskim, Maksymilian Gierymski w pruskim, Brandt w monachijskim (Sienkiewicz 1950a: 73).

Dla świata nie istniejemy - konstatuje z goryczą. Po blisko dwuletnim pobycie w Ameryce Sienkiewicz jest wyjątkowo wyczulony na sprawy polskie, nostalgii towarzyszy jednak bardzo gorzki osąd stanu faktycznego. Wszyscy wymienieni przez niego artyści

\footnotetext{
5 To chociażby przypadek Dygasińskiego z okresu jego „brazylianidy”. Zob. Sztachelska 1997: 86-113.
} 
polscy byli monachijczykami. Oznacza to, że nie mogąc w ojczyźnie kształcić się i rozwijać, skorzystali z gościny Aten nad Izerą (jak nazywano Monachium), by rozwinąć swój talent i odetchnąć powietrzem wolności i sztuki. Po to tam pojechali. W polskim dyskursie artystycznym temat Monachium także $w$ dzisiejszych czasach pozostaje zdominowany przez opinię Stanisława Witkiewicza, z jednej strony pochlebną, z drugiej - niemal druzgocącą. Wspomnienia z pobytu w tym mieście wypełniają sporą część jego studium na temat Aleksandra Gierymskiego ${ }^{6}$. O samej uczelni wyrażał się z szacunkiem, mając w pamięci doświadczenia wcześniejsze, swoje studia artystyczne w Sankt Petersburgu, których nigdy nie cenił:

\begin{abstract}
Akademia monachijska była w owych latach najrozumniej zorganizowanym zakładem wychowawczym dla artystów. Mogła ona wyrządzić minimum szkody, jaką zawsze każdy system kształcenia artystów im wyrządza, ponieważ ściśle biorąc, nie było w niej $\dot{z}$ a d n e g o s y s t e mu. Była ona rozbita na szereg szkól, prowadzonych samodzielnie przez różnych mniej lub więcej zdolnych lub nudnych i niedołężnych profesorów. Przyjęcie do takiej szkoły nie zależało od uprzedniego pobytu w jakiejś niższej klasie, tylko od zdolności ucznia i dobrej woli profesora. Tym sposobem zostawała uczniowi pewna swoboda pójścia za swoimi upodobaniami, pewna możność wcześniejszego określenia się lub uświadomienia się indywidualności (Witkiewicz 1974a: 285; podkr. - J. Sz.).
\end{abstract}

Witkiewicz szczegółowo opisuje w tym studium środowisko polskich artystów, mówi o wzajemnej pomocy, inspiracjach, atmosferze życia, sukcesach i... nędzy. Kreśli sylwetki monachijskich profesorów, nie szczędząc im to gorzkich słów, to szczerego podziwu. Jednocześnie jego wspomnienia są przepojone goryczą. Mimo galerii wypełnionych sztuką, mimo dobrze zorganizowanego rynku sztuki, Monachium jest, było i będzie dla niego prowincjonalną dziurą, bawarskim Mnichowem, w którym wszystko kręci się wokół piwa spożywanego w ogromnych ilościach:

Poza akademią ogarniała nas absolutnie obca sfera sennego, ciasno i typowo niemieckiego miasta, jakim było Monachium wówczas. Ani z temperamentem monachijczyków, ani z tym sposobem życia, ani z tym piwem, które nie tylko co wieczór zalewało ich żołądki, ale przez cały dzień, od świtu do nocy, ciążyło nad całym ich istnieniem [...], ani z innymi stronami życia ludności monachijskiej nie łączyło nas nic. [...] W „niemieckich Atenach”, zapchanych przez króla Ludwika pomnikami, ateńskimi świątyniami, triumfalnymi bramami, w tych Atenach nie było śladu artystycznego ducha, nie było żadnego związku między życiem i sztuką (ibid.: 289).

Można by powiedzieć - żądał za wiele, był ekstremalny w swoich marzeniach, postulatach, oczekiwaniach. Gdzie na kuli ziemskiej jest takie miejsce? Niczym niespokojny duch nigdzie nie znajdował ukojenia. „I po co myśmy tam jechali?” - pytał, i to pytanie stało się legendą. Odpowiedź nie mogła być jednoznaczna, bo dostarczały jej zarówno doświadczenia z zagranicy, jak i z ojczyzny, do której ostatecznie artyści powracali niczym wędrowne ptaki po swych edukacyjnych wojażach. Ale jest w tym żalu i goryczy przerażająca prawda czasu. Wokół spontanicznie wznieconego ruchu artystycznego, w którym pojawiły się wielkie osobowości i takież dzieła - pisał Witkiewicz: „[w kraju] rozciągała się głucha pusty-

6 Monografię Aleksander Gierymski wydrukowała „Biblioteka Warszawska” w 1901 roku, t. II-IV. 
nia [... ]. Nie było ani temperatury moralnej, której dla pojawienia się sztuki żąda Hipolit Taine, ani żadnego, mającego jaki taki autorytet, ogniska wychowawczego" (ibid.: 291). Polska postyczniowa - Witkiewicz mówił tu głównie o zaborze rosyjskim - wciąż jawiła się niczym „krajobraz po bitwie”. W dziedzinie sztuki kompletny zastój, który wynikał z braku profesjonalnych ośrodków kształcenia artystycznego ${ }^{7}$, likwidowanych przez zaborcę od powstania listopadowego, potęgowany jeszcze atmosferą życia zupełnie niesprzyjającą rozwojowi sztuki ${ }^{8}$. Do tego rozproszenie środowiska artystycznego, a wreszcie - co było jego szczególną troską - powszechny anachronizm wyobrażeń na temat sztuki, szkół, profesorów, zagranicy, dominujący w świadomości społecznej.

Kiedy w roku 1882, po paroletnim pobycie za granicą, wróciłem do Warszawy, stosunki artystyczne były niezmienione. To samo obojętne otoczenie, ten sam brak miejsca i współczucia dla ludzi pracujących nad sztuką, ta sama pustka dookoła i ta sama świadomość w sobie, że się jest nikomu na nic potrzebnym. Ludzie w jakikolwiek sposób biorący udział w życiu umysłowym, przedsiębiorący jakieś wydawnictwa, kierujący jakimiś robotami, które stykały się ze sztuką, ujawniali zupełny brak wiadomości i zmysłu potrzebnego do ocenienia wartości uzdolnień i talentów, okazywali zakrzepłą rutynę, niezdolność odczuwania postępu, który się gdzieś indziej dokonał, i zupełne niereagowanie na nowe kierunki i nowe talenty (Witkiewicz 1974a: 357).

W tej całkowitej niemal pustce, kiedy to najbardziej utalentowani artyści polscy zatrudniali się jako ilustratorzy książek i czasopism za marne grosze, nastąpił mały cud. Artur Gruszecki za odziedziczone przez żonę pieniądze kupił upadające pismo „Wędrowiec”, niegdyś porządnie prowadzone przez Sulimierskiego. Trzeba było zrobić w nim wszystko od A do Z, od papieru i czcionek, po treść i ilustracje. W krótkim czasie redaktorzy, nieustannie dyskutujący ze sobą, bo po raz pierwszy coś od nich zależało, dopięli swego - powstało pismo wyjątkowe pod każdym względem. Pismo nowoczesne, by nie powiedzieć awangardowe w treści, rewolucyjne w formie, z ambicjami, które utorowały drogę polskiej i europejskiej sztuce - drogę do głów, do świadomości czytelników - przede wszystkim. Witkiewicz wspominał:

[...] w planie od razu postawiliśmy sobie za zadanie wydobyć na wierzch jak najtęższe siły artystyczne, a pod względem reprodukcji stanąć na równi z najdoskonalszymi wydawnictwami świata. Spełnienie tego zadania polegało na jak najwszechstronniejszym zużytkowaniu talentów, daniu im swobody wykazania najistotniejszych cech, na wydobyciu naprzód tych artystów, którzy dotąd zajmowali drugorzędne lub nie zajmowali żadnego stanowiska w opinii ogólu (ibid.: 360).

Tak więc lata 1884-1887 stały się w biografii Witkiewicza wyjątkowo twórcze. Jako kierownik artystyczny pisma spełniał się jako redaktor i organizator, jako publicysta rozbłysną talentem krytycznym, skutecznie edukując artystycznie czytelników. Jego rozprawy na temat sztuki jak żadne dotąd przyciągały publiczność, wywoływały dyskusje, rozpalały

7 Zob. Masłowski 1976, rozdz. wstępne oraz Micke-Broniarek 2007: 7-29.

8 Mitem jest przekonanie, że pozytywistyczna publicystyka sprzyjała sztuce. Oto fragment Kroniki tygodniowej Bolesława Prusa z 1876 roku („,Kurier Warszawski”, nr 33: 1): „Gusta estetyczne stanowią tylko malutką część potrzeb ludzkich i społecznych [...], nie wolno delektować się nimi tym, którym chleba brakuje". 
polemiczne żywioły. W okresie tym rodzą się liczne artykuły Witkiewicza o profesorach akademii monachijskiej, malarzach polskich i obcych (Chmielowski, Meisonnier, Böcklin, Siemiradzki, Kossak, Brandt), ale przede wszystkim głośny cykl Malarstwo i krytyka u nas, będący kontynuacją sporu (m.in. z Henrykiem Struvem) ${ }^{9}$ na temat estetyki idealistycznej oraz próbą zarysowania jego własnych poglądów, w których pobrzmiewały echa najnowszych zdobyczy estetyki zachodnioeuropejskiej. Ukoronowaniem tych wysiłków krytyka stało się opracowanie i opublikowanie Albumu Maksa i Aleksandra Gierymskich we wspólpracy z bliskim mu jeszcze wtedy Antonim Sygietyńskim (1885).

Od 1886 roku Witkiewicz stale zagrożony gruźlicą coraz częściej odwiedza Zakopane. Wchodzi tam w kręgi towarzyskie, które nakierowują jego uwagę na nową przestrzeń działania - Tatry i twórczość artystyczną górali. Wraz z małżeństwem Dembowskich (Marią i jej mężem Edwardem, etnografem) oraz warszawskim lekarzem Władysławem Matlakowskim Witkiewicz poświęci się nowej pasji, która wyda swoje owoce już w latach dziewięćdziesiątych XIX stulecia. Niespokojny duch znowu daje o sobie znać.

\section{Znikczemnienie i literatura}

W latach osiemdziesiątych pozytywiści nie istnieją już jako grupa pokoleniowa, każda z wielkich osobowości poszła swoją drogą, wiążący ich program wielokrotnie potknął się o rzeczywistość. Hetman ugrupowania (Aleksander Świętochowski) ogłosił bankructwo (Dumania pesymisty, 1876) i ostatecznie uznal, że należy się przystosować (Wskazania polityczne, 1882). Na forum politycznym pojawiają się jednak nowi gracze. Prócz młodych liberałów, którzy utracili już swój młodzieńczy entuzjazm, coraz śmielej występują neokonserwatyści, do których Sienkiewicz wraz z zasileniem redakcji „Niwy”, a potem objęciem „Słowa” nolens volens zgłosił akces. Obok pojawiają się także wyjątkowo hałaśliwi w tym czasie zwolennicy radykalnej prawicy, skupieni w warszawskiej „Roli” ${ }^{10}$, z którymi zresztą wyjątkowo mu nie po drodze. W tle krzepnie i zdobywa coraz więcej zwolenników ruch socjalistyczny.

Dojrzały pozytywizm, którego owoce pojawią się pod koniec tego okresu ${ }^{11}$, nie nosi w sobie optymizmu z początków kampanii. Przeciwnie, można by rzec, że jego szczególną misją stanie się dokumentowanie ideowej miałkości programu, który nie wytrzymał presji rzeczywistości, ale także procesów, które w ogromnej skali dotykają społeczeństwo, zwłaszcza anomii, naznaczającej niemal wszystkie warstwy społeczne i boleśnie poświadczonej w biografiach indywidualnych.

Sienkiewicz w czasie pobytu i tuż po powrocie z Ameryki jest pełen energii i nowych pomysłów, nie ukrywa też krytycznego stosunku do rzeczywistości polskiej, czemu najdo-

\footnotetext{
9 Na temat tego sporu, ale od drugiej strony, zob. Sztachelska 2010: XXX-XLII.

10 Na temat formuły polskości w „Roli” oraz "Wędrowcu” w latach osiemdziesiątych XIX stulecia zob. Paczoska 1999a: 105-118.

11 W późnych latach osiemdziesiątych ukazują się najważniejsze powieści epoki: Lalka (1887), Nad Niemnem (1887), mimo utopijnych akcentów, bynajmniej nie optymistyczne. Powieść polska lat dziewięćdziesiątych głównie naturalistyczna (np. Wysadzony z siodła Antoniego Sygietyńskiego) i premodernistyczna (np. Bez dogmatu Sienkiewicza) - pesymizm ten oddawała jeszcze silniej.
} 
bitniej dał wyraz w pisanym w Stanach dramacie ${ }^{12}$ oraz - już bez autocenzury - w prywatnej korespondencji do Juliana Horaina (Sienkiewicz 1977: 356-414) ${ }^{13}$. Mimo niewątpliwego sukcesu, jaki odniosły jego korespondencje, nie ma ani dobrego humoru, ani dobrej sytuacji ${ }^{14}$. Ta poprawi się z czasem, gdy pisarz pozbędzie się długów (zaciągniętych w związku z kupnem pisma przed wyjazdem do Ameryki), ustabilizuje się zawodowo i w życiu prywatnym. Do końca 1881 roku jest jeszcze związany z „Niwą”, ale od stycznia 1882, także za namową poślubionej w sierpniu 1881 Marii z Szetkiewiczów, staje się redaktorem „Słowa”, organu młodego konserwatyzmu, próbującego połączyć tradycyjne wartości z koniecznością modernizacji społeczeństwa. Na początku swojej działalności redaktorskiej bardzo będzie też dbał o zachowanie rozumnych proporcji i niezależności pisma. Dopiero po zdecydowanym wkroczeniu na drogę stricte literacką (pierwsze sukcesy Ogniem i mieczem), gdy zabraknie mu sił, by dawać sobie radę jednocześnie na polu literatury, w redakcji i walczyć ze śmiertelną chorobą żony, firmowane przez niego „Słowo” zyska zdecydowanie prawicowy odcień, przechodząc na inne zgoła pozycje, niż to na początku planowano. Ta zmiana z pewnością nie uszła uwadze Witkiewicza.

Zanim to się jednak stanie, jeszcze przed Trylogia, piórem swojej żony ${ }^{15}$, anonimowej współpracowniczki „Słowa”, Sienkiewicz określa swój sposób rozumienia polskości. Maria robi to w słynnej polemice ze Spasowiczem, krytykiem literackim, który deklarował się otwarcie jako zwolennik ugody z Rosją. Jego artykuł dotyczył poezji Syrokomli i Wincentego Pola, którego w pewnym momencie zrównywał z pamiętnikarzem Marcinem Matuszewiczem, bezkrytycznym piewcą szlachetczyzny. Maria podzielała krytycyzm Spasowicza dotyczący symplifikacji historii w twórczości Syrokomli, ale ostro sprzeciwiała się manipulacji czytelnikiem. „Chrystusować przeszłość - pisała odważnie - jest przesadą, ale nazwać ją jawnogrzesznicą jest nie mniejszą - i choćbyśmy zgodzili się na to, że dzięki mesjanizmowi mieliśmy głowę w obłokach, to drugi kierunek może przez niebaczność wytrącić nam podstawę spod nóg. Musimy stać na tym, co jest nasze-inaczej przyjdzie spaść gdzieś za nisko, bo aż do stosowania się, »w trzecim czy czwartym pokoleniu do nowych zewnętrznych warunków «, zamiast dążyć do wytwarzania nowych, pomyślniejszych” (Sienkiewicz 1950b: 190). Ta pointa była i błyskotliwa, i trafna. Postawienie na jednym poziomie Matuszewicza (tego „morza ciemności”) i Pola - bezwzględnego narodowca i „katona polskości” - było według niej nie tylko niestosowne, ale i nieuczciwe. Przypominała:

\footnotetext{
12 Chodzi o dramat Na jedną kartę, napisany w 1876 roku w Stanach Zjednoczonych, w którym mamy przeciwstawienie dwóch sił (starej i nowej) dążących do władzy, nieposiadających kwalifikacji moralnych do jej sprawowania. Zob. Budrewicz 1999: 23-40.

13 Szczególnie interesujące listy na temat stosunków warszawskich - 8, 10.

14 Po powrocie do kraju z Ameryki i Europy Sienkiewicz pragnie zmienić swoje dziennikarskie wcielenie. W pierwszym odcinku felietonu, który zaczyna pisywać w 1879 roku dla „Niwy", zapisuje decyzję o zaniechaniu misji naprawiania świata codziennego i zmianie emploi: „Nie mam żadnych powodów do dobrego humoru; jestem raczej jak ów Tomek z Króla Leara, bo zimno mi pod każdym względem. Rzeczywistość, z którą musi mieć do czynienia kronikarz, jest jak zwykle: szara, bezbarwna, smutna, często jałowa - niech więc uprawia sobie tę rolę, kto chce; ja nie mam sił, ochoty i będę mówił o czym innym". Znamienna jest dla tego momentu zmiana nazw jego stałych rubryk - Chwila obecna staje się Mieszaninami literacko-artystycznymi. To świat „myśli i wyobraźni”, ale także „zapomnienia i ucieczki”. Cyt. za Sienkiewicz 1950b: 4.

15 Co do autorstwa tego tekstu nie ma już dzisiaj wątpliwości. Sienkiewicz pisze o tym wyraźnie w liście do J. Horaina: „Ze sprawozdań rozbiór Spasowicza jest pióra mojej żony, która ma główkę wcale nie do pozłoty". Cyt. według H. Sienkiewicz, List do J. Horaina [23, początek stycznia 1882 roku] (Sienkiewicz 1977: 412).
} 
Tajemnica wpływu Pola na współczesnych dla nas nie jest tajemnicą, $[\ldots]$ ten tylko nie może sobie tego wpływu wytłumaczyć, kogo te r a źn i e j z o ść z a d a wa ln i a zupełnie. W tradycji ludzie widzieli tyle złego, ile i Pol sam, ale faktem jest, że tylko ta przeszłość n a m pozostała. [...] Pol nauczył nie tylko współczesnych, ale i przyszłe pokolenia kochać przeszłość - i jako taki ma ogromne znaczenie dla krytyki historycznej - ta bowiem, oparta na miłości, może i musi wydać plon zdrowy i pożyteczny. Inaczej doprowadziłaby tylko do wielkiego nihil - i w sensie społecznym usunęłaby podstawę spod nóg narodu (ibid.: 195, podkr. - J. Sz.).

Był to mocny policzek wymierzony ugodowcom.

\section{Poezja i naturalizm}

Sienkiewicz-felietonista omawia obrazy Witkiewicza w jednym ze swoich felietonów, ale już wcześniej kilkakrotnie wypowiada swoje uwagi na temat jego sztuki w korespondencji prywatnej. Jego listy do przyjaciela cechuje wyjątkowa delikatność. W jednym z nich, z 1881 roku, czytamy: „Wczoraj byłem u Twoich braci. Mówiliśmy dużo o Tobie, Twojej sztuce. Za punkt wyjścia wziąłem Twój obraz Dziewczyna z owca, który lubię raz dla jasnych włosów dziewczyny, a po wtóre dlatego, że poza wykonaniem jest w nim i kompozycja" ${ }^{\text {"16. }}$. To wyraźny ślad jakiejś dyskusji, być może sporu o to, co w dziele sztuki jest najważniejsze. Wydaje się, że właśnie tego dotyczy następny fragment listu, wielce intrygujący: „gdybyś się nie bał własnej poezji i tak właśnie wyrzucał z własnej duszy wszystko, jak czujesz, zostałbyś wielkim malarzem i odzyskał spokój, albowiem dotąd wypowiadałeś swą formę, a tłumiłeś treść, która w Tobie leży” (ibid.). W dalszym ciągu Sienkiewicz podkreśla, że w każdym dziele sztuki naprawdę liczą się tylko dwie rzeczy - poetyczna treść i forma. Przy okazji daje swój pogląd na naturalizm: „Podoba Ci się Jamioł, więc Ci powiem, że gdybym najdokładniej opisał śnieg, las, czerwony nos dziewczyny, a nie złożył tych pierwiastków w kompozycję, rzecz nie robiłaby wrażenia. Byłby to tylko naturalizm” (ibid.).

No właśnie - tylko „naturalizm”. Który z nich ma bardziej uproszczony pogląd? Czy chodzi tylko o estetykę, czy jest w tym coś więcej? Przypomnijmy: Sienkiewicz trzykrotnie zabiera głos w sprawie naturalizmu ${ }^{17}$; jego opinie są zawarte w odczycie $O$ naturalizmie (składa się on z dwóch części, które miały swoją premierę w Warszawie 2 i 9 grudnia 1880 roku; Sienkiewicz 1881c), dwóch recenzjach z 1881 roku: Przeciw Zoli (E. About, Le roman d'un brave homme; Sienkiewicz 1881a) oraz „Numa Roumestan”, powieść A. Daudeta (Sienkiewicz 1881b) oraz eseju Listy o Zoli (Sienkiewicz 1893) z 1893 roku. Bardzo dobrze widać w nich poszerzanie się sposobu rozumienia naturalizmu przez pisarza, który przecież, co trzeba mocno podkreślić, nigdy nie stronił od stosowania tej techniki, by wypomnieć mu choćby Szkice węglem, Jamioła, co bardziej drastyczne sceny Trylogii czy z późniejszych rzeczy Bez dogmatu. Ta ewolucja pojęć polega tu na przejściu od pojmowania naturalizmu jako pewnego typu estetyki, wzbogacającej deskrypcję literacką, do naturalizmu jako koncepcji

\footnotetext{
16 List do S. Witkiewicza z 13 stycznia 1881 roku (Sienkiewicz 2009: 255).

17 Wielokrotnie Sienkiewicz wyraża swoje opinie także w korespondencji prywatnej, zwłaszcza listy do Jadwigi Janczewskiej stanowią ciekawe źródło tych opinii, zob. Sienkiewicz 1996 (cz. 1-3).
} 
antropologicznej. Rzecz jednak nie w tym, że pisarz dojrzewa w swoich poglądach, chodzi raczej o generalną ocenę literatury naturalistycznej, a w zasadzie wyłącznie negatywnego jej oddziaływania na duszę człowieka ${ }^{18}$. Wróćmy jednak do przerwanego wątku.

W liście napisanym po kilku dniach Sienkiewicz znowu powraca do tego problemu, pozwalając sobie na ocenę twórczości Chełmońskiego, jednego z najbardziej uznanych wówczas na Zachodzie twórców, niestety malującego zbyt wiele podobnych kompozycji, by nie popaść w rutynę. W liście do Stanisława Sienkiewicz komplementuje przyjaciela i jednocześnie żartobliwie go poucza: „Co do Chełmońskiego, jest to majster, ale gra ciągle na jednym klawiszu. Ty ponaciągaj wiele wybornych strun na formingę wydrążoną ze skorupy żółwia i maluj wszystko, co rzuca cień pod światłem Heliosa. Gama Twoich uczuć jest bogatsza, niech i ręka będzie skorsza"19. Tu już mamy cały program sztuki: wytrawny esteta używa retoryki homeryckiej, by nakreślić program malarstwa na wskroś intuicyjnego, wrażeniowego, w którym najważniejsze jest światło i uczucie!

We wrześniu tegoż roku o którymś z obrazów Witkiewicza Sienkiewicz pisze znowu w tonie mocno swawolnym: „Obraz Twój jest świetny. Za grosz konwenansu. Prawda, »wraże « mordy znakomite, dziewczyna, która poprawia pałasz, przypomina mi kacenszkiniankę ${ }^{20}$. Pokazywałem go u Bennich dziś”21. W jego dalszej części mamy groteskową scenę przekonywania nabywców do zakupu obrazu. To jeden z tych listów, z których wynika, że pisarz zaangażował się w pomoc przyjacielowi cierpiącemu permanentny niedostatek i zagrożonemu śmiertelną chorobą. Gdy Witkiewicz ofiarował mu obraz i kilka szkiców, Sienkiewicz przy pierwszej sposobnej okazji postanowił je sprzedać. Nie wiemy, jak przyjął to Witkiewicz, istnieje jednak uzasadnione podejrzenie, że właśnie to przecięło nagle ich wyjątkową relację i doprowadziło do rozziewu.

Myślę jednak o jeszcze jednej okoliczności. Od momentu objęcia „Słowa” Sienkiewicz zamieszczał tam oceny dzieł sztuki. Stanowią one bądź integralną część jego Kronik, bądź osobne artykuły. Tak się złożyło, że od początku roku najwięcej pisał o twórczości Jana Matejki: publiczność warszawską informował m.in. o zakupie Hołdu pruskiego, potem analizował słynnego Stańczyka. Obu dziełom nie szczędził zachwytów. W opisie pierwszego z obrazów Sienkiewicz, podkreślając teatralność kompozycji, pisze:

Obraz jest wielki, bo natchniony tu artysta odczuł i wypadek dziejowy, i życie ówczesne, i chwałę narodową, a oddał z potęgą i mistrzostwem. $\mathrm{Z}$ tego powodu mistrzowski ten obraz z jednej

\footnotetext{
${ }^{18}$ W mojej opinii spór o naturalizm między Witkiewiczem i Sienkiewiczem wynika z nieporozumienia. Sienkiewicz interpretuje naturalizm głównie przez twórczość Zoli i inne przykłady z literatury francuskiej (np. A. Daudet, autorzy pomniejsi, nieudolnie naśladujący Zolę, Flaubert jest dla niego przykładem realizmu najwyższej próby) i traktuje je jako dowód wyzbycia się przez tę kulturę sacrum, a zatem i wpływu na ludzkie dusze. Bardzo charakterystyczna dla jego sposobu rozumienia jest recenzja z Numy Roumestama A. Daudeta, w której felietonista pisze na koniec: „Fałsz, hipokryzja, rozpusta, frazes - to konieczności. I nic więcej? - I nic więcej... Nie ma czym odetchnąć - jeden tylko mistral zwiewa miazmaty - a zresztą każdy bożek ludzki widziany z bliska to bałwan dość plugawy, który jeśli ma duszę, to w niej próchno... Czytelnik męczy się, ziębnie i wreszcie mimo woli z goryczą pyta, czy tego próchna nie ma także i w duszy autora" (cyt. za Sienkiewicz 1950b: 206). Swoją drogą Zola jest Sienkiewicz wyraźnie zafascynowany, zob. Sztachelska 2016b: 91-108.

19 List do S. Witkiewicza z 19 stycznia 1881 roku (Sienkiewicz 2009: 259).

20 "Kacenszkinianka”, tu: bywalczyni kawiarni w Katzenstein w Meranie. „Wraże mordy” - z ros. vražyj - straszny, przerażający. Chodzi o obraz, na którym Witkiewicz przedstawił karczmę i jej bywalców, dzisiaj nieznany.

21 List z 20 września 1881 roku (ibid.: 285).
} 
strony zadawalnia do najwyższego stopnia uczucia artystyczne, z drugiej budzi uniesienie, którego podstawą jest duma z tej wielkiej, wspaniałej przeszłości²2

Nawet jeśli - jak wnikliwie peroruje dalej - weźmiemy pod uwagę dzisiejszy krytyczny osąd historyków dotyczący losów państwa brandenburskiego, czego Matejko musiał być w pełni świadom, umieszczając na obrazie smutnego Stańczyka, płótno to budzi podziw dla przeszłości. To niezbędne - pisze Sienkiewicz - byśmy mogli dzisiaj doświadczać otuchy i ulgi. O stronie technicznej obrazu wypowiada się z najwyższym uznaniem: „Nigdy dotąd nie posunął wyżej Matejko sztuki malowania. Wspaniały styl obrazu, potężna charakterystyka figur, siła kolorytu i harmonijność linii idą tu w zawody" (ibid.: 96). Obraz ten stwierdza Sienkiewicz - jest dla nas ważny podwójnie: jest dziełem sztuki, i - choć o tym napisać wprost nie może - przykładem sztuki narodowej.

Jak wiadomo, miało to swój dalszy ciąg. Sienkiewicz zaapelował w swoim artykule o zakup malowidła drogą składek publicznych i udostępnienie go w Zachęcie. Apel podjęto, składki zaczęły napływać, ale sprawa nieoczekiwanie przyjęła inny obrót. Towarzystwo Zachęty ogłosiło nagle, że jeśli w ciągu roku nie zbierze się cała potrzebna suma, pieniądze zostaną przeznaczone na zakup nowych pomieszczeń dla Towarzystwa. W tym czasie Matejko podjął decyzję o darowaniu swojego obrazu Zamkowi Królewskiemu na Wawelu. Sienkiewicz zaproponował natomiast, by nieodebrane składki mogły zasilić konto pla-

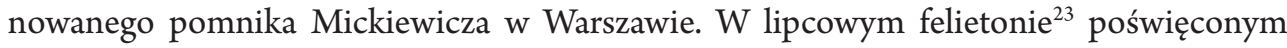
Stańczykowi Matejki oraz innym obrazom, traktowanym jednak zdawkowo, pojawiają się także prace Witkiewicza. W omówieniu poświęcono im najwięcej miejsca.

Sienkiewicz zaczyna od pochwały. Powiada: niewielu artystów maluje tak szczerze jak Witkiewicz. Co namalowane, to odczute wprost i głęboko: „Ze wszystkich młodszego pokolenia artystów Witkiewicz ma najwięcej poczucia natury, a w szczególności polskiej natury" (ibid.: 110). Co to znaczy? Według Sienkiewicza artysta znakomicie potrafi oddać charakter polskiego krajobrazu - równin, ugorów i lasów. W upodobaniu do tego typu malarstwa podobny jest do innych mistrzów pejzażu - Gierymskiego i Grottgera. Od pierwszego różni go to, że nie szuka egzotyzmu, od drugiego - zdecydowanie wyższe rozumienie formy. Nie używając terminologii plastycznej, Sienkiewicz intuicyjnie wychwytuje umiejętności malarza - budowanie subtelnego nastroju ${ }^{24}$ : „Dusza poetyczna a melancholijna odbija się w tych obrazach z nieporównaną szczerością" (Sienkiewicz 1952: 110). Postacie przypominają mu poezję Syrokomli. Pragnąc wydobyć oryginalność Witkiewiczowskich kompozycji, felietonista podkreśla różnice:

Nie dość poezji w duszy, nie dość upodobań i zamiłowań w prostocie, w pustej, melancholijnej przestrzeni, w śniegach, mgłach, szarych chmurach i deszczu. Trzeba to jeszcze umieć rysować

\footnotetext{
22 H. Sienkiewicz, „Hołd pruski”. Obraz Jana Matejki, „Słowo” z 19 maja 1882 roku, nr 110; cyt. za Sienkiewicz 1952: 95.

${ }^{23}$ H. Sienkiewicz, Wystawa Towarzystwa Zachęty Sztuk Pięknych, "Słowo” z 7 lipca 1882 roku, nr 149; cyt. za Sienkiewicz 1952: 106-114.

24 Witkiewicz pisze we wspomnieniu z Monachium: „Ton i Stimmung, czyli nastró j, były to wyrazy, które powtarzały echa szarych korytarzy Akademii, które słychać było wszędzie, gdziekolwiek się zeszli malarze: na ulicach, w pracowniach i w głębi knajp, przy marmurowych porysowanych stolikach, wśród mgły tytoniowego dymu i wyziewów kawy i piwa" (Witkiewicz 1974a: 284).
} 
i malować. Owoż Witkiewicz dlatego jest niepospolitym artystą, że posiada biegłość techniczną i rysunek, doprowadzony naprawdę do doskonałości (ibid.: 111).

W obrazie Rynek - zręcznie ujmuje felietonista - mamy aż nadto dowodów:

Wyobraźnia nie ma [...] nic do roboty. Życie powszednie samo wypowiada wszystko, co jest do powiedzenia. O uczucia obraz także nie potrąca - widzowi tylko pozostaje to zadowolenie, jakie daje prawda uchwycona niezmiernie trafnie na gorącym uczynku i w ogólności (ibid.).

Sienkiewicz kręci nieco nosem na ujęcie postaci - „za twardzi w kolorycie”, ale zaraz dodaje - „szlachetne pojęcie przedmiotu”. W ogóle jego wyobrażenia są dosyć szczególne. W felietonie przywołuje przykład obrazu (bez ujawniania autora), w którym niby wszystko jest poprawne, a jednak dobry smak przekroczono. Widać wyraźnie, że ma smak wykształcony na sztuce klasycznej, pokazującej raczej idealizowane wizerunki ludzi niż realne. Do opisu dzieł sztuki stosuje niemal te same pojęcia, których używa w odniesieniu do literatury, choć przecież dysponuje pewnym rozróżnieniem tych dziedzin, a w każdym razie dobrze wie, że dzieło sztuki jest syntezą czasu i umiejętności interpretacji:

Malarz ze względu na naturę swej sztuki winien szczególniej o dobrym smaku pamiętać. Powieściopisarz daje czytelnikowi ciąg życia; pojedynczą scenę trywialną może zrównoważyć szeregiem innych, poetycznych, wzniosłych - i dzięki tej równowadze zachować szlachetny charakter całości. Malarz oddaje chwilę jedną, jedno mgnienie oka, a zatem o wiele więcej powinien się strzec, by ta jego chwila nie budziła niesmaku (ibid.: 112).

Na szczęście - dopowiada - Witkiewicz przejawia ów takt estetyczny w wysokim stopniu. O obrazie przyjaciela Trzej jeźdźcy wyraża się z najwyższą rewerencją - tu malarz naprawdę jest poetą. Podoba mu się genialne oddanie pory dnia - zimowego zmierzchu „gdy śnieg oświecony zorzą daje blaski fioletowe, a noc ma zapaść pogodna, bywa w owych blaskach i w owym zaciszeniu się natury, w pustoszy pól i w mrocznych masach lasów coś uroczystego i tajemniczego zarazem" (ibid.: 113). Gdybym był gdzieś za granicą i zobaczył ten obraz - pisze - zaraz poczułbym się jak w domu. Przy obrazie Witkiewicza wyobraźnia pracuje sama. Jak to jest możliwe? „Mogę tylko zapewnić, że dzieło sztuki, które tak działa i które pod takim nawałem wrażeń widza zostawia - musi być tworem, poczętym w głębi uczucia, a zrodzonym przez prawdziwy i pełen mocy talent” (ibid.: 113-114).

Czy Witkiewicz, czytając powyższe analizy, mógł być zadowolony? I tak, i nie. Wedle jego pojęć, obrazu nie czyta się jak książki, choć można i trzeba go odczuwać25. Najważniejsza w sztuce jest wierność naturze, tylko ona może być regulatorką naszych wrażeń. Gdy Sienkiewicz pozostawał, nawet bardzo siląc się na zrozumienie przyjaciela, wyznawcą estetyki idealizującej, i jak Struve w gruncie rzeczy myślał o sztuce jako o sferze „urzeczywistniających ideałów”, Witkiewicz nie dbał o temat czy idee, stawiał przede wszystkim na indywidualizm, bo to w jego przekonaniu jedyny dopuszczalny filtr naszych wrażeń. Więc jednak - stali na przeciwległych brzegach.

25 Zob. uwagi E. Paczoskiej (1999b: 209-219). 
Wrócę tu na koniec do sprawy, która jak dotąd, mimo wysiłku kilku zaangażowanych w nią głów ${ }^{26}$, nie znalazła finału. By odpowiedzieć na to, dlaczego się podzielili, co ich do siebie zraziło, odpowiedzi może być kilka. To, co widoczne na pierwszy rzut oka, to coraz bardziej różniąca ich pozycja życiowa. Wraz z poślubieniem Marii Sienkiewicz stabilizuje swój status społeczny i zawodowy, gdy w tym samym czasie Witkiewicz przysłowiowo klepie biedę na warszawskim bruku i bytuje właściwie na marginesie. Mimo to drażni go pomoc Sienkiewicza okazywana przy sprzedaży obrazów i w wyraźnie promujących jego sztukę recenzjach, z których jednak - według pojęć malarza - jasno wynika, że nie rozumie on nowej sztuki. Myślę też, że był to zasadniczy powód, dla którego Witkiewicz - mimo dotkliwej biedy - odmówił Sienkiewiczowi objęcia stanowiska kierownika działu artystycznego „Słowa”. Po 1883 roku pismo zresztą wyraźnie skręciło w prawo. Potem artysta całkowicie odda się swojej misji w „Wędrowcu”. Będzie walczył z przesądami w sztuce, będzie uczył patrzeć na obraz, pokaże, co to prawdziwy artystyczny geniusz. Jednym słowem, aktywność krytyczna pochłonie go na co najmniej kilka lat. Po rozwiązaniu „Wędrowca” i z powodu kryzysu zdrowotnego przeniesie się na stałe do Zakopanego, ale bynajmniej nie spocznie na laurach. W tym czasie Sienkiewicz doświadczy nieba i piekła. Krótka kronika szczęścia rodzinnego zamknie się bowiem śmiercią Marii w październiku 1885 roku, jeszcze przed ukończeniem Potopu. Na świecie zostanie dwoje jego dzieci zrodzonych z tego związku: Henryk Józef i Dzinka (Jadwiga), no i Trylogia ${ }^{27}$ - żywy pomnik wpływu, jaki nań miała zmarła przedwcześnie żona.

Najmniej przekonujący wśród wszystkich używanych do objaśnienia tego momentu w ich biografii argumentów wydaje się ten, że Sienkiewicz obraził Witkiewicza, publikując w 1883 roku Sachema. Nie wydaje mi się możliwe, by normalny, dojrzały człowiek, nawet przesadnie drażliwy, nie zrozumiał subtelnej ironii Sienkiewicza. Treścią Sachema jest znikczemnienie, przyzwyczajenie do niewoli, Witkiewicz o znikczemnieniu mówi i pisze od lat osiemdziesiątych!

\section{Przełom}

Dla obu przyjaciól przełomem okazał się rok 1900. To, przypomnijmy, rok jubileuszu Sienkiewicza, który - jednak! - jest także początkiem potężniejącej reakcji przeciwko $n^{n i e m u^{28}}$. Po 1900 roku twórca Trylogii już nic ważnego nie napisze, kolejne jego powie-

\footnotetext{
26 Zarówno J. Krzyżanowski (1973), jak i Z. Piasecki (1999: 71-100) próbują wyjaśnić blisko siedmioletnią przerwę w ich przyjaźni, wynajdując w celu objaśnienia najróżniejsze powody: 1. Sienkiewicz handluje jego obrazami, „wciskając je” swoim najróżniejszym, zamożnym znajomym; 2. dzielą ich poglądy na sztukę, w tym rozumienie idei i tematu historycznego, pojmowanie naturalizmu; 3. gdy pierwszy coraz głębiej wchodzi w oddziaływanie kręgów konserwatywnych - drugi radykalizuje swoje poglądy. Jeszcze jeden argument podaje Korniłowiczówna; jest to opublikowanie Sachema, tekstu bardzo gorzkiego w swojej wymowie. Zob. na temat tych hipotez: Sztachelska 2003: 176 i n.

27 Ogromna część Trylogii powstaje w czasie śmiertelnych zmagań z chorobą Marii. Ogniem i mieczem pisze Sienkiewicz w Warszawie; Potop - w sanatoriach, do których podróżuje twórca wraz z żoną, szukając na próżno ratunku. Na temat wpływu Marii na męża i symetrii w ich poglądach zob. w artykułach: Sztachelska 2016a: 423-444 oraz Sztachelska 2017: 17-38.

28 Witkiewicz pisze do rodziny w grudniu 1900 roku w Zakopanem:„Dziś u was jubileusz. Jak tylko ludzie czczą wzniosłe myśli i czyny, których treść jest dobra - spełniają dobrą i wzniosłą treść życia. U nas jest już reakcja prze-
} 
ści spotkają się z krytyką, ale i w jego opinii są one przeważnie chybione, nieudane bądź wymuszone $^{29}$. Sienkiewicz pozostaje jednak ciągle postacią numer jeden polskiej kultury, autorytetem i homo politicus, któremu coraz trudniej przychodzi zachować neutralnośćc ${ }^{30}$. Po sukcesie Ludzi bezdomnych (1899) Stefana Żeromskiego pole literatury bezapelacyjnie należy już do nowego pokolenia, które nie tylko wprowadza nowe tematy, ale także stabilizuje się ideowo.

W przypadku Witkiewicza początek nowego wieku okazał się czasem wyjątkowej aktywności. Opublikowanie jego artykułów z lat osiemdziesiątych, które ukazywały się w „Wędrowcu” (Sztuka i krytyka u nas - 3 wydania: 1891-1898) wraz z uzupełnieniami, oraz wydanie nowych i ważnych studiów poświęconych wybitnym artystom (Juliusz Kossak, Aleksander Gierymski, Jan Matejko, Jacek Malczewski) ${ }^{31}$ zainicjowało nową epokę w polskiej refleksji estetycznej - i Witkiewicz odegrał w niej ważną rolę. Nie tylko zresztą w sztuce, bo znacznie poza nią wykroczył. Mówienie o artystach i twórczości zawsze wyzwalało w Witkiewiczu potrzebę mówienia o polskiej kulturze jako całości; w żadnym z jego artykułów czy rozpraw refleksja na temat sztuki nie jest czymś autonomicznym. Kilkakrotnie w tych tekstach Witkiewicz powoła się na lekturę Sienkiewicza. Podobno wśród ulubionych lektur malarza stale znajdowały się pisma Mickiewicza, poezje Słowackiego, Trylogia Henryka Sienkiewicza, Popioły Żeromskiego, powieści i pisma Lwa Tołstoja ${ }^{32}$.

Najciekawsze i jednocześnie najbardziej paradoksalne - już w samym wyborze - są odwołania Witkiewicza do Trylogii i Rodziny Połanieckich. Dlaczego? Legenda Sienkiewicza to w ogromnej części zasługa ekstatycznego przyjęcia Trylogii, z której karmazynowego bogactwa - jak pisał Potocki na początku XX wieku - Polacy długo nie mogli się otrząsnąć (Potocki 1912: 14). Rodzina Połanieckich z kolei to najbardziej zohydzona przez młodopolską krytykę powieść Henryka Sienkiewicza, którego żywym i do dziś świadectwem są często cytowane inwektywy Stanisława Brzozowskiego (Legenda Młodej Polski) o Polsce zdziecinniałej, zeświniałej czy parszywej albo niewybredne passusy pióra Wacława Nałkowskiego (Sienkiewicziana 1904), używającego sobie na Sienkiewiczu ile wlezie ${ }^{33}$. Bezpardonowość tych ataków jest równie mocna, co niesłuszna, a na dodatek w poczuciu jakiejś fałszywie pojętej sprawiedliwości dziejowej (która chciałaby w mocnej sienkiewiczowskiej legendzie uczynić jakiś uszczerbek), dość mocno upowszechniona za sprawą recepcji szkolnej. Ponieważ owa sprawiedliwość wydaje mi się fałszywa, chciałabym użyć narzędzi historyka literatury i wreszcie wyjaśnić, dlaczego w ogóle była możliwa. Bo dla mnie ciekawsze jest co

ciw Sienkiewiczowi i przez to ludzie niedobrze rozumieją, jakim on był dobrem dla naszego społeczeństwa. Ani zaprowadzenie go na ratusz, ani wręczenie Oblęgorka nie jest w żadnym stosunku do jego rzeczywistej zasługi. [...] Z życia prywatnego Sienkiewicza nie wykroi nikt poetycznej legendy - ale jego życie w literaturze to wielka rzecz. Niechże go czczą" (cyt. za Nowakowska 1963).

29 Mowa tu przede wszystkim o próbie reaktywacji pisarstwa historycznego. Groteskowość Na polu chwały każe widzieć w niej dzisiaj bardziej jakąś autoparodię niż intencjonalne zamierzenie twórcze, zob. Sztachelska 2015.

30 Myślę tu przede wszystkim o wykorzystaniu jego autorytetu podczas słynnej warszawskiej manifestacji jedności narodowej w 1905 roku.

31 Wszystkie te teksty powstają do 1908 roku, gdy Witkiewicz musi przerwać swoją działalność ze względu na pogarszający się stan zdrowia.

32 Zob. Kosiński 1928. Potwierdza to również liczba cytacji z tych autorów.

33 Bardzo możliwe, że powodem owego zohydzenia powieści jest jej akceptacja przez krytykę konserwatywną, Tarnowskiego i np. Spasowicza, co stanowi jednak w świetle poglądów Sienkiewicza pewne kuriozum. Zob. Sztachelska 2003: 127-137. 
innego: jak to się stało, że Witkiewicz w tym Sienkiewiczowskim utworze - powszechnie odsądzanym od czci i wiary - zobaczył coś innego?

\section{Znikczemnienie i Polska skarlała}

Dwukrotnie wcześniej użyte określenie „znikczemnienie” dobrze oddaje temperaturę uczuć i emocje, które towarzyszą Witkiewiczowi w oświetlaniu tego, co jego zdaniem stało się w Polsce postyczniowej. Problem ten pojawia się także w jego publicystyce zrodzonej z potrzeby interwencji w rzeczywistość, w artykułach: Bagno (1902) oraz Wallenrodyzm czy znikczemnienie? (1904). Pierwszy z nich nawiązywał do awantury, do której doszło w Zakopanem i która wiązała się ze sprawą dr. Chramca i jego kliki, próbujących podporządkować sobie okoliczną społeczność. Znalazła ona swój epilog w sądzie w 1903 roku, przed którym jako oskarżony stanął Witkiewicz. Jego pełne emocji oskarżenia publikował „Przegląd Zakopiański” w odcinkach prasowych między lipcem i listopadem 1902 roku $^{34}$. To tam sformułował Witkiewicz oskarżenie pod adresem ludzi, którzy - powodowani chęcią prestiżu i władzy - lekceważą sobie dobro społeczne i zdrowie zależnych od nich ludzi, pisał o nikczemności i upadku moralności. Jego powiedzenie „na trzęsawiskach nie można budować” stało się skrzydlatym słowem epoki, a określenie „bagno” zaczęło funkcjonować w znaczeniu moralnej zgnilizny zakopiańskiej elity ${ }^{35}$. Wezwany przed sąd, oskarżenia podtrzymał i ze sprawy wyszedl jako triumfator.

Drugi artykuł z mocną alternatywą w tytule Wallenrodyzm czy znikczemnienie? powstał w 1904 roku jako reakcja na wiadomość o dobrowolnym udziale delegacji szlachty polskiej w uroczystości odsłonięcia pomnika Katarzyny II w Wilnie. Niedopuszczony zrazu do druku, w wersji mocno zniekształconej przez cenzurę ukazał się dopiero w 1917 roku $^{36}$, w całości wyszedł zaś w XX wieku w paryskiej „Kulturze” (Witkiewicz 1977: 3-24). Upowszechnieniu zawartych $\mathrm{w}$ nim poglądów przeszkodziła nie tylko cenzura, ale także wyjazd Witkiewicza do Lovranu, a zaraz potem wydarzenia polityczne: wojna japońska i rewolucja 1905 roku. W tym samym mniej więcej czasie rodziły się inne pisma Witkiewicza np. monografia o Matejce (1905-1908).

Artykuł Witkiewicza jest dramatycznym opisem rozpadu idei Polski, opartym na prowadzonej od lat analizie sytuacji w kraju po upadku powstania styczniowego. Autor dokonuje tu konfrontacji przeszłości, wyrastającej na pożywce romantyzmu politycznego, i teraźniejszości, zagospodarowanej przez pokolenie postyczniowe. Pisze o kulturze zniweczonej przez wojny i niewolę, o totalnym zagubieniu polskiego ducha, rozpadzie idei polskości. Jego zdaniem cezura styczniowa oznacza definitywny kres Rzeczypospolitej pierwszy zbiegał się z końcem epoki napoleońskiej, drugi - z upadkiem Polski szlacheckiej. System wartości, do którego odwoływały się pokolenia dawnych Polaków, dawne wzorce identyfikacji narodowej, przestały, według niego, istnieć: „Idea Polski, która przedtem dla

\footnotetext{
${ }^{34}$ Opisy niecnych praktyk dr. Chramca i jego kliki wydano też w postaci broszury: Witkiewicz 1903.

35 Zob. komentarz M. Janion (1990: 624): „Bagno staje się symbolem Polski skarlałej i upadłej w błoto, »Polski zeświniałej«, mówiąc językiem Stanisława Brzozowskiego. U Micińskiego pojawiają się takie słowa jak Moczar i Trzęsawisko na oznaczenie stanu dusz polskich tonących w podłości i martwocie".

${ }^{36}$ Opublikowany w: „Kultura Polski” 1917, zeszyt: czerwiec-lipiec.
} 
wszystkich ludów była wcieleniem najszczytniejszych przejawów życia zbiorowego, zmalała, zszarzała, skurczyła się do pojęcia odrębności etnograficznej, do ciasnego, małostkowego, organicznego, egoistycznego zasklepienia się w utrzymaniu byle jakiego bytu" (ibid.: 8).

Te ponure diagnozy rozszerzał krytyk w monografii Matejko, ukończonej w 1911 roku, pisanej właściwie przez całe życie, gdyby wziąć pod uwagę wcześniejsze wersje różnych wypowiedzi Witkiewicza na temat malarza, podlegających, jak powszechnie wiadomo, znamiennej ewolucji: od ostrego zwalczania szkoły historycznej w malarstwie polskim w latach osiemdziesiątych XIX stulecia i samego Matejki, zwłaszcza jako wykładowcy i mistrza w krakowskiej Szkole Sztuk Pięknych, do uznania jego mistrzostwa i podkreślania szczególnej roli dla zachowania polskiej sztuki i plemienności ${ }^{37}$. Diagnozy polityczne utworzyły IV rozdział książki (ukończony przez Witkiewicza w Zakopanem w 1908), znowu z powodów cenzuralnych nieopublikowany w pierwszym wydaniu. Krytyk podkreślał, że Matejko był spadkobiercą epoki, która wykołysała genialnych artystów strzegących wielkości polskiej duszy. Tacy byli dla niego romantyczni poeci - Mickiewicz, Słowacki. W sztuce widzieli nie tyle swój indywidualny interes, co rodzaj posłannictwa mającego na celu „utrzymanie, podniesienie i wzmożenie ducha narodowego". Zanim życie Matejki zgasło, dokonała się jednak w Polsce radykalna zmiana - tak radykalna, pisał Witkiewicz - „jakiej nie przeżyła ona od czasów, kiedy Bolesław Chrobry koronował się w Gnieźnie, i od czasów, kiedy Stanisław August składał koronę w Grodnie" (Witkiewicz 1974b: 341). W czasach porozbiorowych idea Polski dająca o sobie znać w kolejnych konwulsyjnych próbach scalenia tego, co rozdarte, oczyściła się z pierwiastków egoistycznych, stając się dążeniem o charakterze uniwersalnym, mającym na celu idee braterstwa ludów. Najwyższe ucieleśnienie tej idei Witkiewicz znajdował w twórczości Mickiewicza, rzecznika wolności wielu narodów, wchodzących niegdyś w skład dawnej Rzeczypospolitej. Najgłębszym wyrazem tych poglądów, tekstem kultowym stały się przeto Mickiewiczowskie Księgi narodu i pielgrzymstwa polskiego. Mimo że Polska nie istniała na mapie, idea Polski nadal była silna, dając ludziom czującym się Polakami poczucie sensu istnienia.

W IV rozdziale monografii Witkiewicz przekonująco kreśli rozpad Polski spod sztandarów Orła, Pogoni i Archanioła, spowodowany oddolnym ruchem emancypacji ludu będącego dotąd w poddaństwie, i przyznając, że było to nieuniknione, bo takie jest prawo życia. Pisze o tym obrazowo: „Żaden Matejko nie będzie już malował złączonych sztandarów Litwy i Polski, z wiarą we wspólne życie tych ludów. Wszystko to stało się tylko legendą miniętym słupem drogowym, a słupów, raz miniętych, już się na swojej drodze nie spotyka” (ibid.: 345). Ale na ten nieunikniony i spodziewany przecież proces nałożył się inny, przez Witkiewicza nazwany w artykule Wallenrodyzm czy znikczemnienie? „pogromem”:

W pogromie tym ginęła Polska - ta Polska, która dla ówczesnego Polaka stała się żywą istotą, która wcielała w siebie całą sumę pojęć, wierzeń, uczuć, wzruszeń, która napawała nasze dusze wszechobecnością, skupiała je, jakby w jakim kościele, którego była Bogiem (Witkiewicz 1977: $7-8)$.

37 W ośmiu artykułach składających się na cykl Malarstwo i krytyka u nas („Wędrowiec" 1884, nr 52; 1885, nr 5-9, 12, 16-17) w kilku mamy refleksje na temat twórczości i działalności J. Matejki, najsłynniejsze: Malarstwo i krytyka u nas oraz "Największy" obraz Matejki, późniejsze: odczyt Jan Matejko (1903), który powstał na zamówienie studentów Towarzystwa Bratniej Pomocy Uczniów Akademii Sztuk Pięknych w Krakowie, i monografia Matejko ukończona w marcu 1911 roku w Lovranie. 
Ten pogrom to skurczenie się idei polskiej do samego tylko przetrwania, do chęci przeżycia za wszelką cenę, to zgoda na to, by Polska była li tylko pojęciem etnograficznym. Pisze Witkiewicz:

Naród polski pod trzema zaborami i w swoich koloniach pozaeuropejskich okazuje niesłychaną siłę życia. Nic nie jest w stanie powstrzymać jego przyrostu liczebnego ani jego rozwoju cywilizacyjnego [...] a jednocześnie ten naród głośno, jawnie, dobitnie mówi, że „wyrzekł się marzeń" ${ }^{38}[\ldots]$. Chcemy żyć, wołają, żyć po polsku, i pozwólcie nam żyć, bo my „wyrzekliśmy się marzeń”, my chcemy pozostać na zawsze w niewoli za cenę dobrobytu i oświaty, pełnej miski, całych portek i polskiego elementarza - my do żadnej Polski nie dążymy, my jesteśmy lojalni i legalni poddani Prus, Austrii i Rosji ... To jest ta dzisiejsza Polska, to są raczej dzisiejsi Polacy. Czy to jest naród Wallenrodów - czy też naród niewolników? Niestety, raczej to ostatnie! (Witkiewicz 1974b: 346-347).

Nie dziwię się, że cenzura nie przepuściła tych słów gorzkich dla każdego. Tych obrazów, tych wykrzyknień, tego nadzwyczajnego żaru:

Nie ma Polski! Pruscy hakatyści i rosyjska czarna sotnia lepiej o nas myślą, niż na to zasługujemy.

Ale naród polski jest - dzielny, pracowity, uspołeczniony, pyszna rasa ludzi, która w najcięższych warunkach życia dokonywa cudów w zakresie spraw społecznych, w zakresie „pracy organicznej”, w zakresie kultury, rasa, w której jest materiał na bohaterów - tylko ten naród zapomnial "n a u stach wy ra z u"39, ten naród nie wie, jaka jest jego Ojczyzna, te n naród chce się zamienić w sytych i wykształconych niewolników o trójlojalnym su mi en iu. Oto jest ta straszna bezwzględna przemiana, która zaszła w życiu Polski. Rozpadła się jej dawna budowa polityczna i znikła myśl o niej z dusz polskich. I jeżeli kiedy, myśląc o Polsce, można w ostatniej rozpaczy zawołać: „O j c z y z n a! K a w a 1 sk rwaw i o n e g o bło ta!” - to dziś (ibid.: 349 , podkr. - J. Sz.).

W skarlałej Polsce trudno było żyć artystom. Gierymskiemu - który „był bardziej malarzem niż ktokolwiek inny", Witkiewiczowi - niepoprawnemu marzycielowi i irracjonalnemu patriocie, ale też Sienkiewiczowi, który napatrzywszy się świata, po powrocie z Ameryki do kraju w 1879 roku, „marznie jak poor Tom” z Szekspirowskiego Leara ${ }^{40}$. Przypominają się zapożyczone od Mickiewicza słowa Witkiewiczowskiej opowieści:

W tych czasach [...] skorupa była sucha, brudna i plugawa, bardziej może niż kiedy i kto ją tylko znał, kto nie wiedzial, co się dzieje w głębi, ten pluł i wzdrygał się ze wstrętu lub tonął w roz-

\footnotetext{
38 Witkiewicz nawiązuje tu do słynnego powiedzenia cara Aleksandra II, który w 1856 roku podczas wizyty w Warszawie miał rzucić Polakom: „Point de reveries, Messieurs”, co znaczyło: „Koniec marzeń, panowie!” (marzeń o wolności, autonomii Królestwa etc.).

39 Witkiewicz przypomina tu słynny wiersz Słowackiego (pierwsza zwrotka): Szli krzycząc: „Polska! Polska!” - wtem jednego razu Chcąc krzyczeć zapomnieli na ustach wyrazu; Pewni jednak, że Pan Bóg do synów się przyzna, Szli dalej krzycząc: „Boże! Ojczyzna! Ojczyzna!”. Wtem Bóg z Mojżeszowego pokazał się krzaka, Spojrzał na te krzyczące i zapytał: „Jaka?”.

40 Zob. przyp. 14.
} 
paczy. To, co wtenczas stanowiło naczelną warstwę społeczeństwa, przedstawione jest z taką nadzwyczajną prawdą w Rodzinie Połanieckich. To społeczeństwo, z którego wypruto wszelkie idee i zastąpiono je interesem, społeczeństwo płaskich spekulantów, płytkich miłostek, uganiania się za łatwym powodzeniem i robienia sobie cnoty obywatelskiej ze zręcznego bogacenia się; to społeczeństwo, w którym zdaje się szczęściem, jasnością i weselem umrzeć jak Litka lub pogrzebać się żywcem w rezygnacji jak pani Emilia; to społeczeństwo było takie, że żyć z nim było niepodobna, trzeba się było powiesić, uciekać - lub żyjąc wśród niego, żyć poza nim, co jest łatwiejszym, niż się na pozór wydaje (Witkiewicz 1974a: 310-311).

Czy Witkiewicz pisze tu tylko o sobie?

\section{Idea polska}

Myśl o Polsce niepodległej jest niewątpliwie obsesją Witkiewicza. Nic zatem dziwnego, że po 1900 roku, gdy dało się odczuć spore ożywienie w kwestii narodowej, jego diagnozy wcześniejsze i całkiem bieżące znalazły nowy oddźwięk. Szczególne niebezpieczeństwo „obniżenia idei narodowej” dostrzegł on tam, gdzie programowo na sztandarach wywieszano polskość - ale zmniejszoną, przykrojoną do nowej „polityki realnej”. Taki złowieszczy projekt najpierw odczytał w pozytywizmie, ale także w karnawalizacji zachowań konserwatystów krakowskich, bawiących się z jednej strony w „historyczne” rekonstrukcje, z drugiej - zawsze gotowych do lojalizmu, potem zaś (co uznał za szczególnie niebezpieczne $)^{41} \mathrm{w}$ programie stronnictwa narodowo-demokratycznego, które na łamach „Przeglądu Wszechpolskiego" reprodukowało zdegenerowaną wersję zachowania narodowości za wszelką cenę. Niebezpieczeństwo zawsze pobudzało zmysł polemiczny Witkiewicza. W tym sensie każda z jego rozpraw powstałych po 1900 roku była poniekąd interwencją.

Idea polska ma w ujęciu Witkiewicza przede wszystkim charakter moralny, jest wiernością wobec wartości duchowych, które w przeszłości ukształtowały naród. Spośród nich najwyższe uznanie miało zawsze, według Witkiewicza, polskie umiłowanie wolności, kształtujące indywidualizm polskiego etnosu. By go odzyskać, należało przede wszystkim obudzić sumienie, dumę i ducha narodowego. W pismach Witkiewicza zarysowuje się, jak pisze przekonująco Małgorzata Vražić (2013), całościowa wizja takiego programu odnowy. Program ten składa się z trzech kroków. Cytuję za autorką opracowania:

1. Narodowość i plemienność - wskrzeszenie narodowego ducha miało przynieść odrodzenie idei Polski. Witkiewicz mówil, jak być Polakiem, odwołując się do mitu, będącego składnikiem paradygmatu romantycznego, powieści Henryka Sienkiewicza i malarstwa Juliusza Kossaka czy Jana Matejki, których twórczość wykorzystał dla własnych celów.

2. Wychowanie, przebiegające pod patronatem filozofii Fryderyka Nietzschego, które miało wieść do reedukacji (estetycznej i etycznej) społeczeństwa, a w konsekwencji do wychowania Nowego Człowieka, którym jest artysta, filozof (myśliciel) i świecki święty, zaangażowany społecznie.

${ }^{41}$ Pisze o tym Olszaniecka 1984: 200. 
3. Architektura i styl zakopiański - jako zworniki całej koncepcji. Architektura i sztuka to uniwersalny system komunikacyjny. Witkiewicz traktował polską kulturę jako przestrzeń do zagospodarowania i jako zaginiony tekst, wymagający reinterpretacji. Odwoływał się do metafory domu i katedry oraz kategorii „pierwotności” pierwiastków sztuki i architektury Podhala. Styl zakopiański był projektem utopijnym, ale utopia to jeden z języków epoki (ibid.: 51).

\section{Mityczne regiony polskości}

Zdaniem Witkiewicza sztuka polska w wieku XIX najsilniej i w sposób nieskażony żadnym wpływem zewnętrznym wyrażała polskiego ducha. Artyści i pisarze byli według niego depozytariuszami idei polskości. Nigdy nie godził się na upodrzędnienie sztuki, bo - jak twierdził - podstawową właściwością sztuki jest zdolność wytwarzania nowych, żywotnych i życiodajnych treści. Tu poza tym - utrzymywał - dokonuje się najbardziej naturalna synteza tego, co dawne, i tego, co nowe, przyszłościowe. Dlatego wśród jego bohaterów znajdujemy zarówno wyrastającego ponad epokę Aleksandra Gierymskiego i Jacka Malczewskiego, jak i tradycjonalistów - Jana Matejkę czy Juliusza Kossaka. Żaden projekt narodowy - przekonywał - nie uda się bez tych postaci.

W poświęconych im monografiach Witkiewicz refleksję nad ich twórczością dopełnia własnymi przemyśleniami, które ujawniają niepospolitą osobowość autora, pasję, wzniosłość wyznawanych idei. Najsilniej zaznacza się to w rozprawie o Juliuszu Kossaku, który w ocenie krytyka nie tylko przestawał być artystą konwencjonalnym, odpornym na prądy sztuki światowej, co uosabiał polskość w czystym stanie, był wyrazicielem malarskiego szlacheckiego genre'u w sztuce polskiej ${ }^{42}$. Innym wybitnym przykładem wydaje się Matejko, z którym Witkiewicz najpierw walczy143 ${ }^{43}$ częściowo z pewnością słusznie, a którego potem, w odczycie i monografii (Jan Matejko, Matejko) wykreował na geniusza obdarzonego absolutnym darem wsłuchiwania się w ducha narodowego. Wcześniej odsądzanego od czci i wiary docenił wreszcie i postawił na piedestale. Widział w nim depozytariusza idei Polski, odnowiciela gatunku historycznego, utalentowanego realistę.

W tym panteonie znalazłoby się także miejsce dla Sienkiewicza, jak sądzę, do którego Witkiewicz po latach się przekonał. Być może przeczytał go na nowo ${ }^{44}$, a może także - z po-

\footnotetext{
42 Recenzenci pracy Witkiewicza podkreślali, że autor monografii jest przede wszystkim artysta. Zob. np. Tetmajer 1900. Zdecydowanego ataku na autora dopuścił się w wieloodcinkowym artykule jego dawny współpracownik, Antoni Sygietyński (1900, nr 314-316, 320-324), zarzucający mu liczne uproszczenia (np. w obrazie pozytywizmu) i niefachowość. Ten bezpardonowy atak wygląda niestety na osobiste jakieś nieporozumienia i porachunki.

43 Być może zrozumiał swój błąd i chciał go naprawić? Bezwzględność jego sądów jest oczywista. Ponieważ pierwsze wydanie Matejki znalazło się pod obstrzałem krytyki zawsze chętnej do wypomnienia autorowi jego pomyłek, a on sam ze względu na ciężki stan zdrowia odpowiedzieć nie mógł, w jego obronie wystąpił Antoni Kamieński (Kamieński 1909: 138-144). Sam zainteresowany do wydania drugiego dołączył obszerne wyjaśnienia, w których mówi o stałości swoich opinii. Zob. Witkiewicz 1974b: 353-366.

44 Maria Olszaniecka cytuje wypowiedź Witkiewicza, będącą reakcją na pierwszą lekturę: „Przeczytałem tu Ogniem i mieczem, a Zagłoba jeden zostaje na wierzchu, jak się w to bardziej wczytuję i akcja przestaje robić wrażenie. Cóż za niezliczone mnóstwo fars i konceptów. Cała powieść razem z historią i bohaterami jest tylko krzemieniem do wykrzesania iskier tego dowcipu" (List do Sygietyńskiego, cyt. za Olszaniecka 1984: 205). Reakcja jest co najmniej zastanawiająca - to odkrycie satyrycznego charakteru Trylogii, skądinąd słuszne, ale u człowieka pokroju Witkiewicza?
} 
wodu pewnej izolacji czy oddalenia spowodowanego chorobą - patrzył na niego inaczej niż pozostali, zwłaszcza zaś ci, którym Sienkiewicz po 1900 roku był ze swoimi sukcesami na niwie krajowej i za granicą solą w oku? Nie trzeba specjalnie przekonywać, że mimo powszechnego (a często i bezkrytycznego) uwielbienia, stałej obecności w prasie, niestroniącej od reklamiarstwa i manipulacji wizerunkiem artysty, autor Trylogii i jego pisarstwo na początku XX wieku wydawało się już pieśnią przeszłości. Krytyczne uwagi pod jego adresem historyk literatury wyłuska nie tylko z oficjalnych rejestrów tzw. kampanii antysienkiewiczowskiej, która wybuchła na łamach „Głosu” warszawskiego i pism sprzymierzonych w 1903 roku, ale także z korespondencji prywatnej twórców, którzy wiele mu zawdzięczali - np. Reymonta. W nowych okolicznościach Sienkiewicz wydawał się monetą nieco już wytartą, młodzi pragnęli głosu świeżego, bezkompromisowego. Jest paradoksem, że takim głosem, mimo restrykcji cenzury, mówił do wszystkich ... tylko Witkiewicz. W monografii Juliusz Kossak w kilku akapitach przypomniał, kto w latach osiemdziesiątych, gdy duch polski tężał w nikczemności, obezwładniony strachem i karmiony obłudą, rzucił wyzwanie tym, co o Polsce zapomnieli ${ }^{45}$ : „Taką chwilę przeżyło nasze społeczeństwo, kiedy w nieukołysany jeszcze wir, zatoczony przez ruch pozytywistyczny, Sienkiewicz rzucił swoje Ogniem i mieczem" (Witkiewicz 1974a: 7). Zdumienie musiało być ogromne - pisze Witkiewicz.

Autor Szkiców weglem, Janka Muzykanta, Bartka zwycięzcy, autor mnóstwa fejetonów, w których wołał o postęp, o światło, w których przetrzepywał zdziurawioną przez mole tradycję, ten, który nie wierzyłl, „żeby wóz społeczny tak leciał w przepaść, żeby pod jego koła trzeba było podkładać dokumenta wymagane u kanoniczek", ten człowiek z Teki Worszyłly zawrócił nagle na miejscu i poszedł, jak się zdawało, na przełaj ruchowi, do rozbudzenia którego w tak znacznej mierze się przyczyni (ibid.).

Pierwsza część Trylogii - pisze bez ogródek krytyk - wywołała konsternację, gwałtowną krytykę ze strony postępowców czy konkurentów na niwie historycznej. Ale po pewnym czasie nadeszło jakby oprzytomnienie:

Z tych kart buchnęła nagle żywiołowa siła plemienna; spod całego samokrytycyzmu, pozytywizmu, pracy organicznej odezwało się silne i czyste echo tych samych drgnień duszy [...]. Społeczeństwo, które przez kilkanaście lat usiłowało wyjść z siebie, które miało tylko „socjalne” dążenia, które goniło za nowymi pojęciami, hasłami, często po prostu za wyrazami z zachodu, które zdawało się zapominać „na ustach wyrazu”, nagle uświadomiło swoją szczególną odrębność, odnalazło w swojej duszy treść wspólną z tymi, którzy poprzez zmienne losy dziejów kładli swoje kości ,jako sztandary wojsk zatraconych...” (ibid.: 8).

Ogromnym osiągnięciem pisarza - podkreśla Witkiewicz - stało się to, że warstwy społeczne, które z kulturą szlachecką wiązała tylko „tradycja niewoli i wyzucia z praw ludzkich”, w jego dziele zobaczyły swoją duszę. Krytyk nazwał to, co ich do Trylogii przyciągnęło: to nienaruszona, elementarna energia życia, siła, która pozwala przetrwać mimo zmiennych kolei losu, nędzy, nieszczęścia czy głupoty. Właśnie ją, tę elementarną siłę życia, lud rozpoznał w Trylogii: „Z powieści Sienkiewicza wydobyła się nie tylko bierna świadomość

45 Jedyną pracą współczesną, która w sposób bardzo gruntowny przebadała fundament historyczno-społeczny tamtych czasów, przed wybuchem Trylogii, jest praca S. Sandlera Wokół Trylogii z roku 1952, dająca najszerszy pogląd na to, w jakich warunkach powstawała powieść Sienkiewicza i przeciwko komu mogła być wymierzona. 
narodowej odrębności, buchnęła z nich elementarna siła narodowego życia”, która - jak pisze dalej Witkiewicz - określa żywotność narodu. „Naród stanowi tylko ta elementarna siła jego osobowości, ta niepokonana żywotność jego treści plemiennej, która ogarnia całość życia i nadaje wszelkim jego przejawom swoją szczególną cechę" (ibid.: 9) ${ }^{46}$.

Witkiewicz nie ma wątpliwości, że od tego czasu coś zmieniło się w społeczeństwie polskim. Sienkiewicz niczym magnetyzer przebudził społeczeństwo z letargu, w którym było pogrążone. Odnotowali to m.in. historycy literatury, np. Antoni Potocki, piszący z przejęciem, że w latach osiemdziesiątych naród „stworzył samego siebie” (Potocki 1912: 7). Ważne jest w tym kontekście i następne zdanie Witkiewicza, wyjęte z rozprawy, dla mnie może najważniejsze:

Literatura nasza od owego czasu nie zatrzymała się ani na chwilę w swoim rozwoju. Poszła dalej i wyżej, głębiej i bezpośredniej sięgnęła w życie, z surową powagą ujawniła tragedię dusz ludzkich, znalazła jeszcze większą potęgę słowa, jeszcze skuteczniejszą moc opanowywania umysłów - ale tamta chwila odrodzenia absolutnej energii życia nie może być przekreślona przez nikogo (Witkiewicz 1974a: 9-10).

Tych słów, tak pochlebnych, w żadnym wypadku nie należy interpretować w kontekście wzajemnych relacji obu artystów, zwłaszcza zaś, co nie jest powszechnie znane - stałej i dyskretnej opieki roztaczanej przez Sienkiewicza nad chorym przyjacielem ${ }^{47}$. One naprawdę są ewenementem! Tym bardziej że dzisiaj mamy do czynienia z sytuacją całkowicie odmienną - status obowiązkowej wykładni poglądu na temat Trylogii mają raczej opinie Stanisława Brzozowskiego („Nie darmo zachwyca się nią umysł tak rdzennie polski, jak Witkiewicz...”48) czy Czesława Miłosza („Trylogia nie jest tak niewinna...”49). Podobnie zresztą, jak jedyna „słuszna” interpretacja Rodziny Połanieckich, w której około 1903 roku środowisko „Głosu”, a zwłaszcza jadowicie usposobiony wobec Sienkiewicza Nałkowski ${ }^{50}$ zobaczyli dowód moralnej korupcji jej autora.

To, co jednak na przełomie XIX i XX wieku przydawało kolorytu małemu, wewnętrznie skłóconemu środowisku prasowemu Warszawy czy Krakowa, dzisiaj nie ma już zgoła sensu i nie wypada się tym kontentować. Siła argumentów Nałkowskiego, Brzozowskiego, a także żartownisiów w postaci Tadeusza Żeleńskiego-Boya czy Adolfa Nowaczyńskiego, nie jest już taka jak kiedyś. Maria Olszaniecka pisze: „Tego wyrazu polskiego witalizmu w dziełach Sienkiewicza nie mógł dopatrzeć się S. Brzozowski, który, odwrotnie, niż Witkiewicz, uważal, iż [epopeja Sienkiewicza] jest właściwie karykaturą polskości, apoteozą tego wszystkiego, co było w niej najlichsze”. I dalej: „Witkiewiczowi chodziło o obudzenie siły,

\footnotetext{
46 Znajdował ją także w kulturze górali tatrzańskich, w sztuce ludowej.

47 Pisze o tym m.in. Olszaniecka 1984: 403.

48 S. Brzozowski: „Nie darmo zachwyca się nią umysł tak rdzennie polski, jak Witkiewicz. [...] Niech mi tylko nikt nie mówi o krzepkości plemiennej, która na zaledwie ostygłych zgliszczach straszliwej pożogi, pod obuchem wroga zdobywa się na taką pogodę. [...] Popularność Sienkiewicza pośród warstw ludowych to z a ra z a szlacheckiego lenistwa duchowego zaszczepiona im" (Brzozowski 1971: 73, 84).

${ }_{49}$ Cz. Miłosz: „Trylogia jest mniej niewinna niż to z pozoru wygląda. Jej bohaterowie z sarmackiego praiłu ulepieni, archetypalni, w sarmackie życie z kolei wracają z kart powieści, a niektóre ich popędy, przez Sienkiewicza niedomówione, w życiu nabierają dobitności. Rzeklibyśmy, że Trylogia kryje w sobie niewywołaną kliszę, kiedy ją wywołają odpowiednie warunki, wyłania się z niej twarz archetypalnie sarmacka, Gnębona Puczymordy" (Miłosz 1990: 89).

50 Chodzi oczywiście o Sienkiewicziana (1904) Wacława Nałkowskiego, w których Rodzina Połanieckich jest nicowana na wszystkie możliwe sposoby.
} 
Brzozowskiemu o obudzenie określonej siły" (Olszaniecka 1984: 205-206). Jeszcze gorzej wygląda sprawa z Rodziną Połanieckich ${ }^{51}$, która przez Sienkiewicza została pomyślana jako opis tworzącej się warstwy mieszczańskiej, z wyraźną intencją demaskatorską. To miało być po Bez dogmatu drugie ogniwo obrazu Polski współczesnej, skonstruowane na zasadzie: „Zobaczcie, dzisiejsza Polska to Płoszowscy i Połanieccy”! Do takiej interpretacji uprawniają zarówno jej satyryczny entourage, jak i głęboka ironizacja warstwy narracyjnej powieści, którą jednak - jakby wbrew temu wszystkiemu - ciągle czyta się jako apologię filisterstwa, groszoróbstwa i innych plag polskich, łatwo dostrzegalnych także u współczesnych naszych rodaków. I bynajmniej nieprowokujących do śmiechu.

Podsumowanie tego stanu rzeczy może być jedno tylko: ad fontes, wróćmy do źródeł. Do Witkiewicza. Czytajmy niedoczytanych - a odsłonią przed nami inne światy.

51 Zob. interpretację tej powieści w moim artykule Italia Henryka Sienkiewicza (Sztachelska 2017: 114-141).

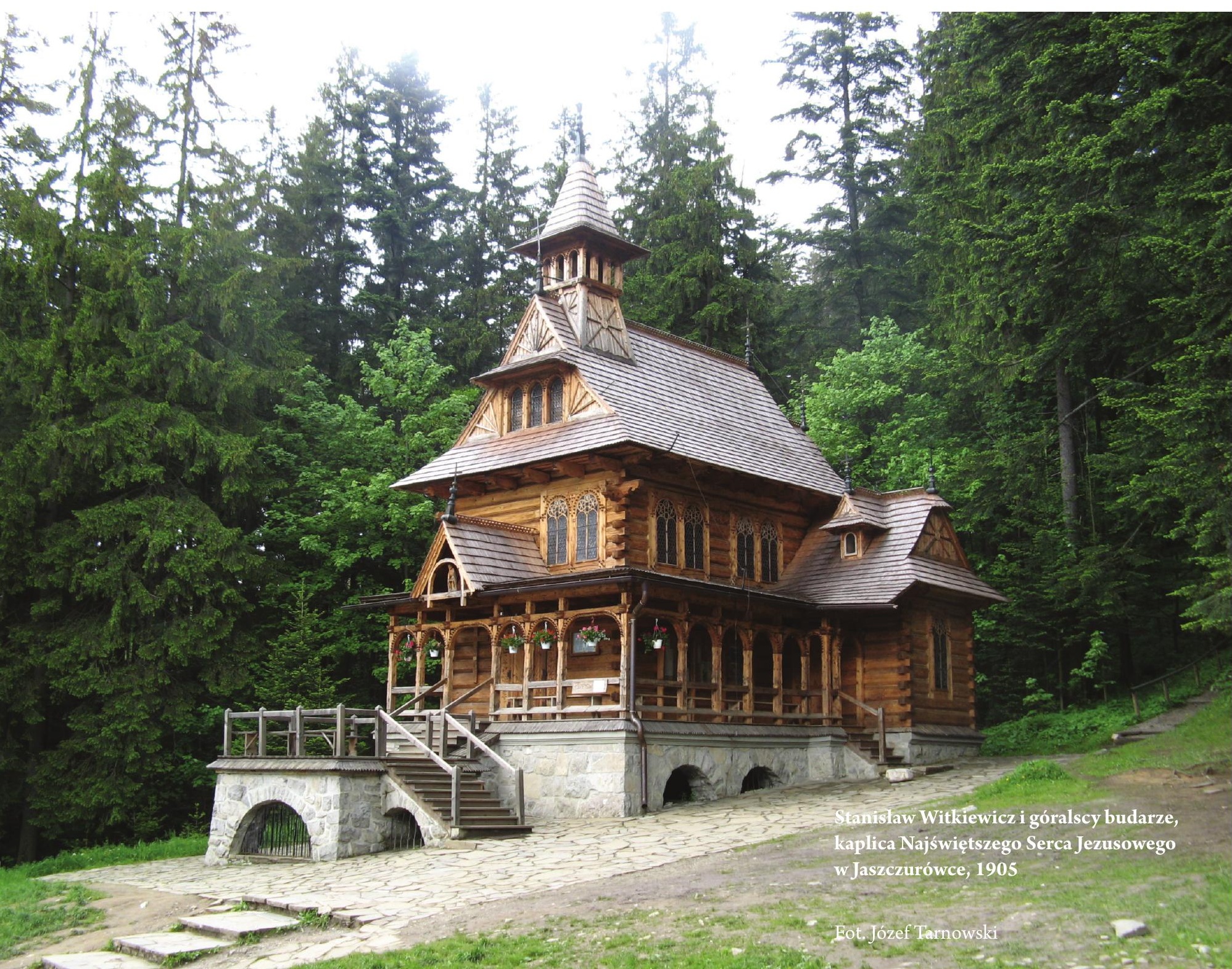




\section{Bibliografia}

Błoński, Jan 2003. Witkacy na zawsze. Kraków: Wydawnictwo Literackie.

Brzozowski, Stanisław 1971. Współczesna powieść i krytyka literacka. Warszawa: Państwowy Instytut Wydawniczy.

Budrewicz, Tadeusz 1999. „Na jedna kartę. Początek czy koniec epoki”. W: Ewa Ihnatowicz (red.). Sienkiewicz i epoki. Powinowactwa. Warszawa: Instytut Literatury Polskiej Wydziału Polonistyki Uniwersytetu Warszawskiego.

Janion, Maria 1990. Życie pośmiertne Konrada Wallenroda. Warszawa: Państwowy Instytut Wydawniczy.

Kamieński, Antoni 1909. „Głos do redaktorów. (Kilka słów z powodu wydrukowanej w nr 10 »Kraju« recenzji pana Jana Obsta o książce »Matejko« St. Witkiewicza)”. Sfinks 6: 138-144 .

Kosiński, Kazimierz 1928. Stanisław Witkiewicz. Warszawa: Instytut Wydawniczy „Biblioteka Polska”.

Krzyżanowski, Julian 1973. „Sienkiewicz i Witkiewicz (Karta z dziejów niezwykłej przyjaźni)”. W: Julian Krzyżanowski. Pokłosie Sienkiewiczowskie. Szkice literackie. Warszawa: Państwowy Instytut Wydawniczy.

Masłowski, Maciej 1976. Maksymilian Gierymski i jego czasy. Warszawa: Państwowy Instytut Wydawniczy.

Micke-Broniarek, Ewa 2007. Malarstwo polskie. Realizm, naturalizm. Warszawa: Wydawnictwo „Arkady”.

Miłosz, Czesław 1990. Homer i Gnębon Puczymorda. W: Czesław Miłosz. Prywatne obowiązki. Olsztyn: Pojezierze.

Modrzejewska, Helena 1957. Wspomnienia i wrażenia. Przeł. Marian Promiński. Kraków: Wydawnictwo Literackie.

Nałkowski, Wacław 1904. Sienkiewicziana: szkice do obrazu. Kraków: Drukarnia Narodowa.

Nowakowska, Wanda 1963. „Stanisław Witkiewicz o Sienkiewiczu i innych”. Życie Literackie 587: 4.

Olszaniecka, Maria 1984. Dziwny człowiek (O Stanisławie Witkiewiczu). Kraków: Wydawnictwo Literackie.

Paczoska, Ewa 1999a. „Polskość w dobie niewoli - gniazdo czy »zaścianek«?”. W: Janusz Maciejewski (red.). Przemiany formuly polskości $w$ drugiej połowie XIX wieku. Warszawa: Instytut Badań Literackich PAN.

- 1999b. Sienkiewicz i awangardy. W: Ewa Ihnatowicz (red.). Sienkiewicz i epoki. Powinowactwa. Warszawa: Instytut Literatury Polskiej Wydziału Polonistyki Uniwersytetu Warszawskiego.

Piasecki, Zdzisław 1999. Stanisław Witkiewicz w kręgu ludzi i spraw sobie bliskich. Szkice nie tylko biograficzne. Opole: Uniwersytet Opolski.

Potocki, Antoni 1912. Polska literatura wspótczesna. Cz. 2: Kult jednostki 1890-1910. Warszawa: Gebethner i Wolff, Kraków: G. Gebethner i Spółka.

Prus, Bolesław 1876. „Kronika tygodniowa”. Kurier Warszawski 33: 1-3.

Pycka, Anna Małgorzata 2010. Kreacje i poglądy Stanisława Witkiewicza na tle głosów epoki. Kraków: Towarzystwo Autorów i Wydawców Prac Naukowych „Universitas”.

Handler, Samuel 1952. Wokót „Trylogii”. Wrocław: Wydawnictwo Zakładu Narodowego im. Ossolińskich.

Sienkiewicz, Henryk 1881a. „Mieszaniny literacko-artystyczne VIII”. Niwa 17.

— 1881b. „Mieszaniny literacko-artystyczne XVIII”. Niwa 20.

- 1881c. „O naturalizmie w powieści”. Niwa 2.

- 1893. „Listy o Zoli”. Stowo (31 lipca-1 sierpnia). 
— 1950a. Dzieła. Red. Julian Krzyżanowski. T. 44: Listy z podróży i wycieczek. Warszawa: Państwowy Instytut Wydawniczy.

- 1950b. Dzieła. Red. Julian Krzyżanowski. T. 50: Mieszaniny literacko-artystyczne. Warszawa: Państwowy Instytut Wydawniczy.

— 1952. Dzieła. Red. Julian Krzyżanowski. T. 53: Uzupetnienia, t. 1. Warszawa: Państwowy Instytut Wydawniczy.

- 1977. Listy. Red. Julian Krzyżanowski. Oprac. Maria Bokszczanin. T. 1, cz. 2. Warszawa: Państwowy Instytut Wydawniczy.

- 1996. Listy. Oprac., wstęp i przypisy Maria Bokszczanin. T. 2, cz. 1-3 (Jadwiga i Edward Janczewscy). Warszawa: Państwowy Instytut Wydawniczy.

— 2009. Listy. T. 5, cz. 2: Aleksandra Ulanowska - Józef Żychoń. Listy. Oprac., wstępem i przypisami opatrzyła Maria Bokszczanin. Warszawa: Państwowy Instytut Wydawniczy.

Sygietyński, Antoni 1900. „Juliusz Kossak w oświetleniu St. Witkiewicza”. Kurier Warszawski 314: 1-3; 315: 1-3; 316: 1-3; 320: 1-2 ; 321: 1-2; 322: 1-2; 323: 1-2; 324: 1-2.

Sztaba, Wojciech 1982. Gra ze sztuką: o twórczości Stanisława Ignacego Witkiewicza. Kraków: Wydawnictwo Literackie.

Sztachelska, Jolanta 1997. Dygasiński i „brazyliańskie” epopeje. W: Jolanta Sztachelska, „Reporteryje” $i$ reportaże. Dokumentarne tradycje prozy polskiej w 2 pot. XIX i na pocz. XX wieku: (Prus-Konopnicka-Dygasiński-Reymont). Białystok: Wydawnictwo Filii Uniwersytetu Warszawskiego.

- 2003. Czar i zaklęcie Sienkiewicza. Studia i szkice. Białystok: Wydawnictwo Uniwersytetu w Białymstoku.

— 2010. „Henryk Struve - estetyk doby przejściowej”. W: Henryk Struve, Wybór pism estetycznych. Wprowadzenie, wybór i opracowanie Jolanta Sztachelska. Kraków: Towarzystwo Autorów i Wydawców Prac Naukowych „Universitas”.

— 2015. „Wilk a sprawa polska. Dwie opowieści”. W: Jerzy Axer, Tadeusz Bujnicki (red.), Sienkiewicz $z$ innej strony. Warszawa: Wydawnictwo DiG.

— 2016a. „Żona pisarza. Na marginesie listów Marii z Szetkiewiczów Sienkiewiczowej”. Wiek XIX. Rocznik Towarzystwa Literackiego im. Adama Mickiewicza IX (LI).

— 2016b. „Wobec Zoli”. Biatostockie Studia Literaturoznawcze 8: 91-108.

- 2017. Mity sienkiewiczowskie i inne szkice tylko o nim. Warszawa: Wydawnictwo DiG.

Tetmajer, Kazimierz 1900. „Witkiewicz o Kossaku”. Tygodnik Ilustrowany 48: 950-952.

Vražić, Małgorzata 2013. Stanisław Witkiewicz i Witkacy - dwa paradygmaty sztuki, dwie koncepcje kultury. Warszawa: Wydział Polonistyki Uniwersytetu Warszawskiego.

Witkiewicz, Stanisław 1884. „Malarstwo i krytyka u nas”. Wędrowiec 52: 622-623, 626.

— 1885. „Malarstwo i krytyka u nas”. Wędrowiec 5: 49-51; 6: 63-64; 7: 74-75; 8: 86; 9: 98-100; 12: 134-136;16: 182-184; 17: 196-197, 200.

— 1901. „Aleksander Gierymski”. Biblioteka Warszawska II-IV.

— 1903. Bagno. Lwów: nakł. Towarzystwa Wydawniczego.

— 1917. „Wallenrodyzm czy znikczemnienie?”. Kultura Polski (czerwiec-lipiec): 267-288.

— 1974a. „Juliusz Kossak; Aleksander Gierymski”. W: Stanisław Witkiewicz. Pisma zebrane. Red. Jan Zygmunt Jakubowski, Maria Olszaniecka. T. 2: Monografie artystyczne, cz. 1. Rozprawa wstępna i komentarz Maria Olszaniecka. Kraków: Wydawnictwo Literackie.

— 1974b. „Matejko (1838-1893)”. W: Stanisław Witkiewicz. Pisma zebrane. Red. Jan Zygmunt Jakubowski, Maria Olszaniecka. T. 2: Monografie artystyczne, cz. 2. Rozprawa wstępna i komentarz Maria Olszaniecka. Kraków: Wydawnictwo Literackie.

— 1977. „Wallenrodyzm czy znikczemnienie?”. Kultura 7/8: 3-24.

Żeromski, Stefan 1928. Przemówienie o Sienkiewiczu. W: Stefan Żeromski. Elegie i inne pisma literackie i społeczne. Warszawa-Kraków: T-wo Wydawnicze w Warszawie. 